\title{
DISCIPLINA OU RESSOCIALIZAÇÃO? RACIONALIDADES PUNITIVAS, TRABALHO PRISIONAL E POLÍTICA PENITENCIÁRIA
}

\author{
Bruno Amaral Machado e Marcos Aurélio Sloniak
}

\section{RESUMO}

O OBJETO DESTE ARTIGO É A IMPLANTAÇÃO DA POLÍTICA VOLTADA AO TRABALHO PRISIONAL EM REGIME FECHADO NO DISTRITO FEDERAL. AS PESQUISAS REALIZADAS INDICAM QUE, NO BRASIL, O TRABALHO PRISIONAL, ESPECIALMENTE NO REGIME FECHADO, A DESPEITO DE SUA POSIC̣ÃO CENTRAL NO MODELO CLÍNICO REABILITADOR (ART. $1^{\circ}$ DA LEP), OCUPA POUCO ESPAÇO NA AGENDA POLÍTICA. AS ESCASSAS INICIATIVAS MOSTRAM A DEFICIENTE IMPLANTAÇĀO DAS AÇÕES DIRECIONADAS À INSERÇÃO DO TRABALHO PRISIONAL NO REGIME FECHADO. ESSA ANÁLISE INICIAL SUGERE DIFERENTES QUESTIONAMENTOS. SE O TRABALHO PRISIONAL SE CONSTITUI EM INSTRUMENTO CENTRAL DO MODELO IDEALIZADO NA LEP, QUE RAZŌES EXPLICAM A ESCASSA EFETIVIDADE DO COMANDO LEGAL? DE QUE FORMA O TRABALHO PRISIONAL PERDE ESPAÇO NAS PRÁTICAS E ROTINAS DOS ATORES QUE PARTICIPAM DO PROCESSO DE GESTÃO PENITENCIÁRIA E EXECUÇÃO PENAL? A PARTIR DE ANÁLISE DOCUMENTAL E ENTREVISTAS EM PROFUNDIDADE, ESTE ARTIGO TEM POR OBJETIVO ANALISAR AS REPRESENTAC̄ÕES SOCIAIS DE ATORES SOCIAIS DIRETAMENTE ENVOLVIDAS NA IMPLANTAÇÃO E EXECUÇÃO DA POLÍTICA Penitenciária no Distrito Federal. Pretende-se, ASSIM, A PARTIR DESSA ESTRATÉGIA METODOLÓGICA, ADENSAR O CONHECIMENTO SOBRE AS PRÁTICAS DO SISTEMA PRISIONAL NO BRASIL.

\section{PALAVRAS-CHAVE}

RACIONALIDADES PUNITIVAS; REPRESENTACÕES SOCIAIS; TRABALHO PRISIONAL; POLÍTICA PENITENCIÁRIA; DISTRITO FEDERAL.
DISCIPLINE OR RESOCIALIZATION: PUNITIVE RATIONALITIES, PRISON WORK AND PENITENTIARY POLICY

\section{ABSTRACT}

THIS ARTICLE INTENDS TO DISCUSS THE WORK ON THE PRISON SYSTEM IN THE FEDERAL DISTRICT. DESPITE THE PRISON WORK IS A FUNDAMENTAL TASK IN THE PENAL EXECution LaW (ARTicle 1), IT HaS a Limited IMPORTANCE IN THE POLITICAL AGENDA. THIS ANALYSIS LEADS TO SOME QUESTIONS: IF WORK IN PRISON IS IMPORTANT AS AN INSTRUMENT OF REHABILITATION, WHAT EXPLAIN THIS LACK OF RELEVANCE? HOW THE WORK IN PRISON IS NEGLECTED IN THE POLITICAL AGENDA OF THE ACTORS INVOLVED IN THE ADMINISTRATION AND EXECUtion of THE PENAL EXECUtION LAW? USING IN-DEPTH INTERVIEWS, THE OBJECTIVE IS TO ANALYZE THE SOCIAL REPRESENTATIONS OF THE SOCIAL ACTORS WHO DEAL WITH THE PENITENTIARY POLICIES IN THE FEDERAL DISTRICT. THUS, THE PURPOSE IS, FROM THIS METHODOLOGICAL APPROACH, TO GET TO KNOW THE PRACTICES OF THE BRAZILIAN PENITENTIARY SYSTEM.

\section{KEYWORDS}

PUNITIVE RATIONALITIES; SOCIAL REPRESENTATIONS; INMATE WORK; PENITENTIARY POLICY; FEDERAL DISTRICT. 


\section{INTRODUÇÃO}

A filosofia iluminista influenciou o surgimento do Estado constitucional de Direito, parte de um longo processo de diferenciação funcional entre os sistemas político e jurídico. A diferenciação interna do subsistema jurídico-penal pode ser observada como capítulo maior no qual se insere o iluminismo penal entre os séculos XVIII e $\mathrm{XIX)} .{ }^{1}$ Apesar das divergências internas e distintas especificidades de autores como Cesare Beccaria, Francesco Carrara, Romagnosi e Feuerbach, identificam-se proposições e argumentos estruturantes dos princípios penais do Estado Liberal de Direito (ANITUA, 2007, p. 125 e ss; BECCARIA, 1999, p. 35; HEGEL, 1994, p. 36; LINS E SILVA, 1991, p. 17; KANT, 2003, p. 176).

A idealização de critérios racionais para limitar a intervenção do Estado constitui apenas uma das dimensões do processo de racionalização jurídico-penal. Concomitantemente à diferenciação do sistema jurídico opera a diversificação dos discursos que legitimam a intervenção penal (MACHADO, 2012, p. 77-116). A fundamentação do poder punitivo encontrou, por influência da filosofia utilitária, finalidades distintas para as penas. Ao longo dos últimos 200 anos, as racionalidades punitivas se tornaram mais complexas e ambiciosas.

O caráter retributivo do castigo logo cederia espaço - e passaria a conviver -, por influência do utilitarismo de Bentham, às teorias preventivas da pena (BENTHAM, 2002, p. 21; VON LISZT, 1995, p.82; ANITUA, 2007; p. 190; ZAFFARONI, 2011, p. 127). Nesse cenário difundiu-se o pretenso efeito dissuasório da pena (prevenção geral negativa). Em outras palavras, a ameaça de imposição do castigo seria útil na nova engenharia do Estado moderno. No final do século XIX, o discurso criminológico positivista e a sua versão correcionalista incrementaram as racionalidades das penas ao idealizar a sanção penal como mecanismo de prevenção especial, tanto positiva quanto negativa. Na vertente negativa da prevenção especial, sob inspiração da ideologia da defesa social, a pena foi concebida como instrumento para afastar o criminoso do convívio social (LOMBROSO, 2001, p. 266; FERRI, 1999, p. 137; GAROFALO, 1997, p. 89).

A vertente positiva da prevenção especial, inspirada na possibilidade de reintegração social e que deu origem às variações das ideologias "re" (reabilitação, ressocialização, reintegração), configurou um dos objetivos declarados na modernidade penal (ZAFFARONI, 2011, p. 116 e ss.). O modelo ressocializador estabiliza-se ${ }^{2}$ como programa jurídico que capta racionalidade concorrente do poder punitivo ao longo do século XX, na esteira da transição do Estado Liberal de Direito ao Estado Intervencionista, especialmente do pós-guerra (ANITUA, 2007, p. 481. Observadores atentos da inserção do novo modelo, em contrapartida, denunciaram as finalidades latentes ou não declaradas das novas estratégias punitivas. O ideal reintegrador dissimularia a estratégia disciplinadora das teorizações e práticas do sistema de justiça criminal (GOFFMAN, 1999, p. 16; FOUCAULT, 2007, p. 56). 
As diversas racionalidades punitivas encontraram terreno fértil no sistema político. A produção legislativa constitui lócus privilegiado para compreender os interesses, dinâmicas e contradições da legitimação da pena. As peculiaridades históricas, os interesses políticos e os diferenciais de poder das comunidades epistemológicas que participam e disputam a hegemonia dos saberes penais são relevantes para a reconstrução dos processos que levam à tradução dos discursos penais ao direito positivado (programas do sistema jurídico). ${ }^{3}$ Tais discursos legitimam e justificam a criação de políticas públicas em diferentes momentos da intervenção penal. Em outras palavras, justificam políticas penais (criminalização, definição das funções das diferentes organizações) e penitenciárias.

No jogo da política, não raramente, o discurso punitivo foi alçado ao texto constitucional. As constituições da Itália e da Espanha são paradigmáticas, pois exemplificam a tradução do modelo reintegrador ao status de comando constitucional. Outros Estados trilharam caminhos distintos. No caso brasileiro, o ecletismo penal pode ser observado no art. 59 do Código Penal, que pretende contemplar tanto a finalidade retributiva quanto a preventiva (geral) da pena (CARVALHO, 2007, p. 19; ZAFFARONI, 2011. p. 116 e ss.). Ao longo dos anos, em razão de novas configurações políticas e disputas entre comunidades epistemológicas que participam do campo jurídico-penal, foram contempladas e privilegiadas novas racionalidades punitivas. A Lei de Execução Penal (LEP), de 1984, constitui-se em texto fundamental para compreender a concorrência de distintas racionalidades punitivas. Inspirada pela prevenção especial positiva, estrutura-se a partir do ideal transformador da subjetividade do condenado.

O modelo articula-se segundo ideário próprio, define e estabelece tarefas que devem desempenhar determinadas organizações e atores que participam da divisão do trabalho penitenciário. A filosofia penal "reintegradora" positivada expressamente na LEP deveria inspirar práticas e ações concretas.

Este artigo concentra-se no trabalho prisional em regime fechado, que pode ser concebido em um modelo legitimado pelo ideal retributivo ${ }^{4}$. Em outras palavras, a pena como castigo institucional. Nesse sentido, como parte das medidas que subministram o castigo, pode associar-se ao conceito de dor e penitência. Sob o viés utilitário, na sua vertente preventiva especial positiva, é reconstruído como instrumento ou mecanismo para a transformação das subjetividades.

Nessa nova semântica, o trabalho prisional pode configurar parte da estratégia reabilitadora. Certamente, há pouco espaço para a ingenuidade. A ressocialização constituise em conceito polissêmico e abre espaço para medidas nem sempre compatíveis com o conceito de autonomia dos sujeitos de direito. Dificilmente articulável com o não menos problemático conceito de "dignidade da pessoa humana" sem uma investigação detalhadas sobre a diversidade de técnicas e estratégias de intervenção que supõem as ideologias "re". ${ }^{5}$ Não há espaço neste artigo para uma investigação detalhada sobre o tema, que merece aprofundamento futuro. 
O tema foi abordado sob diferentes perspectivas pela literatura na área. Foucault apontou as funções latentes da prisão, instituição que atuaria como dispositivo de disciplina. Nessa leitura, o trabalho prisional surge como parte da estratégia disciplinar da modernidade (FOUCAULT, 2007, p. 204-205). Essa visão é objeto de diferentes análises, inclusive entre os criminólogos críticos. Baratta aponta os riscos da total deslegitimação do ideal reabilitador, na medida em que abre espaço para o fortalecimento do neorretribucionismo e para as práticas inocuizadoras (prevenção especial negativa) (BARATTA, 1991, p. 253).

As pesquisas realizadas indicam que, no Brasil, o trabalho prisional, especialmente no regime fechado, a despeito de sua posição central no modelo clínico reabilitador (art. $1^{\circ}$ da LEP), ocupa pouco espaço na agenda política. As escassas iniciativas, além disso, mostram a deficiente implantação das ações direcionadas à inserção do trabalho prisional no regime fechado. ${ }^{6}$ Essa análise inicial sugere diferentes questionamentos. Se o trabalho prisional se constitui em instrumento central do modelo idealizado na LEP, que razões explicam a escassa efetividade do comando legal? De que forma o trabalho prisional perde espaço nas práticas e rotinas dos atores que participam do processo de gestão penitenciária e execução penal?

O objetivo inicial é mapear ações políticas direcionadas à implantação do trabalho para condenados no regime fechado no Distrito Federal. Em seguida, pretende-se analisar as representações sociais dos atores sociais diretamente envolvidos na criação e na execução da política penitenciária brasileira. As representações sociais constituem-se em imagens e símbolos construídos socialmente a partir das interações que ocorrem entre o indivíduo e a sociedade (JOVCHELOVITCH, 2004, p. 20-31), e derivam das representações coletivas, idealizadas por Durkheim e retomada pela psicologia social (MOSCOVICI, 2003, p. 167-214), representando ferramenta metodológica importante para a pesquisa sociológica (PORTO, 2006, p. 250-273).

Nesta proposta teórica, considera-se a existência de diferentes procedimentos interpretativos na construção social da realidade (BERGER, LUCKMANN, 1999, p. 96; SCHÜTZ, 1993, p. 112-115). O texto legal constitui-se apenas o ponto de partida, pois é reconstruído a partir de diferentes pautas culturais e, no caso das organizações, segundo rotinas cognitivas sedimentadas a partir de práticas reiteradas que atuam como itinerário para configuração e ressignificação da realidade.

\section{Metodologia da PeSQuisa}

Entre julho de 2013 e janeiro de 2014, entrevistamos ${ }^{7}$ atores que ocupam posições relevantes, tanto na gestão quanto na execução da política penitenciária no Governo Federal e no Distrito Federal. Entre os gestores, participaram da pesquisa quatro servidores que ocupam posições relevantes na hierarquia do Departamento Penitenciário Nacional (Depen), do Conselho Nacional de Política Criminal e Penitenciária (CNPCP) e do 
Poder Executivo do Distrito Federal. Tais organizações, conforme explicaremos em seguida, desempenham papéis fundamentais na concepção, elaboração e implantação da política penitenciária nacional e distrital. Entrevistamos, ainda, três executores, servidores do Governo do Distrito Federal que participam da execução da política penitenciária local, quatro juízes de direito com experiência na Vara de Execução Penal do Tribunal de Justiça do Distrito Federal e Territórios e três promotoras de justiça que atuam nas Promotorias de Execução Penal do Ministério Público do Distrito Federal e Territórios.

A opção pela metodologia qualitativa contemplou cenário diversificado em que os atores selecionados representam instituições distintas e cujas competências se complementam no complexo institucional da execução penal brasileira. Assim, a seleção dos sujeitos da pesquisa decorreu da análise macroambiental relacionada à execução penal. A LEP estabelece as atribuições e competências de cada instituição que compõe o sistema responsável pelo planejamento, execução e fiscalização das políticas penitenciárias.

A opção das entrevistas em profundidade com gestores do governo federal (Depen e CNPCP) mostrou-se relevante, pois trata dos atores incumbidos da discussão e elaboração de políticas penitenciárias voltadas para o trabalho prisional, e de como o trabalho no regime fechado está inserido na política penitenciária. Após mapear as políticas penitenciárias no âmbito do Governo Federal, o foco dirigiu-se à implantação das referidas políticas no Distrito Federal, onde a atribuição recai na Fundação de Amparo ao Trabalhador Preso (Funap) ${ }^{8}$ - Fundação vinculada à Secretaria de Justiça e Cidadania, instituída para fomentar, implementar e gerenciar as oficinas, dentro das unidades prisionais, voltadas para o ideal reintegrador social da LEP. ${ }^{9}$ Nessa fase, as entrevistas em profundidade foram realizadas com gestores e executores das políticas penitenciárias no Distrito Federal.

Em seguida, foram realizadas entrevistas com os magistrados e promotores de justiça, atores privilegiados da fiscalização da execução penal, cujas competências estão relacionadas na LEP. Apesar da relevância funcional, há poucos estudos que evidenciem suas crenças, tensões e expectativas em relação à função que desempenham. ${ }^{10}$

A organização judiciária de cada Estado prevê uma ou mais varas responsáveis por essa área. A definição dos juízes de direito convidados para a pesquisa pautou-se pela experiência na área de execução penal no Distrito Federal. Em relação às promotorias de justiça, o convite dirigiu-se às seis promotorias existentes, das quais três titulares foram entrevistadas.

Após a definição dos atores em cada esfera de atribuição, foram emitidos convites com a descrição da pesquisa desenvolvida e a finalidade almejada. Como ressaltado, optou-se pelas entrevistas em profundidade, com duração entre 45 e 90 minutos (DUARTE, 2006, p. 62).

Os sujeitos da pesquisa são observadores privilegiados do sistema penitenciário brasileiro e distrital. No decorrer das entrevistas, o guia inicial foi apenas o ponto de 
partida, pois os extensos relatos tangenciaram outras questões, cruciais para a nossa interpretação. Ao mapear as diferentes imagens e percepções sociais das elites do sistema penitenciário brasileiro, pretende-se compreender os valores e crenças que orientam as práticas sociais relacionadas à execução das penas, especialmente no que tange ao trabalho prisional no regime fechado no Distrito Federal.

\section{A Teoria das Representações Sociais (TRS) como categoria TEÓRICA DE ANÁLISE}

A Teoria das Representações Sociais (TRS) constitui-se em ferramenta metodológica para análise social. Nessa abordagem, o foco é direcionado aos saberes produzidos em relação a uma determinada realidade social. Assim, pretende-se perquirir o imaginário de determinados atores ou grupos sociais sobre uma questão específica; e os discursos são privilegiados como matéria-prima para a construção analítica (PORTO, 2006, p. 250-273).

A compreensão de um dado fenômeno relaciona-se à forma como os atores selecionados - ou um determinado grupo social - constroem argumentos explicativos e elaboram a partir de experiências do senso comum. Nessa perspectiva, cabe indagar sobre os valores explicitados nas representações sociais, pois direcionam práticas e interações sociais. O estoque de conhecimento comum, na forma de mitos e valores, torna-se crucial para a análise sociológica.

Ao privilegiar a análise dos fenômenos sociais a partir das representações sociais, parte-se do pressuposto de que estas, embora articuladas por vivências individuais, relacionam-se aos papéis e formas de inserção social dos atores. Assim, sugerem determinadas percepções sobre a realidade e possíveis explicações dos fenômenos. No entanto, não são os atores meros coadjuvantes, mas ativos na configuração do espaço social e sugerem signos que indicam a orientação das condutas. Trata-se, assim, de base para a investigação social (PORTO, 2010).

As crenças, valores, ideologias e saberes nativos são valorados não por espelharem o real, mas por aportarem conhecimento social (MOSCOVICI, 1994, p. 7-16). Nesse enfoque, ação social e representação social estão articuladas, pois as expressões subjetivas atuam, direta ou indiretamente, na definição de ações e nos espaços das interações e interdependências. Nessa perspectiva, as representações sociais não são racionais ou irracionais, mas objeto do conhecimento, a serem submetidas à análise sociológica (MOSCOVICI, 2003, p. 167-214). Assume-se que as representações sociais não equivalem aos fenômenos sociais, mas se constituem em dado real ao ser metodologicamente analisado. A pesquisa orientada metodologicamente pelas representações sociais redireciona o olhar para os valores, mitos e crenças, na medida em que são relevantes para a compreensão do social. Assim, as ações sociais e as representações sociais articulam-se diretamente, pois estas orientam práticas e interações sociais. 


\section{O TRABAlHo PRisional NA AgENdA dA POlítica PENitenciária:} PROPOSIÇÕES E DIRETRIZES

Entre 2007 e 2013, o governo federal lançou programas de política penitenciária que contemplam, entre outras áreas, o trabalho prisional. Em 2007, o Programa Nacional de Segurança Pública com Cidadania (Pronasci), composto de 94 ações articuladas em 14 ministérios e estruturadas em grandes eixos de Segurança Pública, previa também a modernização das instituições de Segurança Pública e do Sistema Prisional. ${ }^{11}$ Essa modernização focava na abertura de 41 mil novas vagas até 2011, em especial presídios para a faixa etária entre 18 e 24 anos, com condições mínimas para cumprir o ideal da "reintegração social", com salas de aula, laboratórios de informática e biblioteca nas unidades prisionais. ${ }^{12}$

Mudanças legislativas na LEP também estimularam a remição da pena pelo estudo e implementação de ações voltadas para a educação e capacitação do preso "mediante implementação de projetos educativos, esportivos e profissionalizantes". ${ }^{13}$

A criação de oficinas industriais dentro das unidades prisionais pretendia propiciar ambiente adequado para a reintegração social do condenado disponibilizadas aos estados por meio de convênio, com foco na costura industrial e costura de bolas, atendendo às características regionais das unidades. As metas do Pronasci eram acompanhadas por um Plano Diretor, elaborado pelos Estados e Distrito Federal para expor os resultados obtidos no Programa. Segundo dados do Depen, o Distrito Federal elaborou um Plano Diretor em outubro de 2007, cuja atualização dos dados foi feita em maio de 2010.

Em 2007, o Distrito Federal considerou que "as ações voltadas para programas de reintegração social ainda estavam muito aquém dos padrões desejáveis” e a falta de recursos humanos seria o principal obstáculo para a expansão dessas atividades. ${ }^{14}$ Em 2010, o Distrito Federal afirma que reativou oficinas nas penitenciárias do Distrito Federal (PDF e PDF II), instalou padaria mais moderna, ${ }^{15}$ transferiu oficinas entre unidades e acenou a possibilidade de edificar fábrica de colchões. Contudo, detectou-se obstáculo à expansão de atividades laborais nas unidades prisionais pois, com a inadimplência da Funap por causa de dívidas de INSS, frustraram-se novos convênios. ${ }^{16}$

Outro programa relevante, desenhado pelo Depen, foi lançado pelo Governo Federal em 2011. O Programa Nacional de Apoio ao Sistema Prisional (PNASP) tinha o objetivo de "zerar o déficit de vagas feminino e reduzir o número de presos em delegacias de polícia, transferindo-os para cadeias públicas”, além da abertura de 42,5 mil vagas no sistema prisional entre 2012 e 2014. ${ }^{17}$ Embora o PNASP tenha privilegiado a construção de cadeias públicas, os recursos também previram a abertura de vagas com a construção de colônias penais e penitenciárias. Dados oficiais sugerem que entre 2011 e 2012 foram entregues 7.193 vagas em 11 estados brasileiros com o uso de recursos federais na construção ou reforma de penitenciárias e 
centros de detenção, sempre com a contrapartida financeira dos Estados (MINISTÉRIO DA JUSTIÇA, 2013, p. 6).

Importante destacar que as novas vagas devem atender à Resolução n. 9 do CNPCP, cuja implantação sinaliza avanços nos espaços de cada unidade prisional, impondo aos Estados a implantação de oficinas nas penitenciárias e nas colônias penais agrícolas, industriais ou similares (CNPCP, 2011, p. 51). O planejamento das unidades visa "favorecer as pessoas presas no desenvolvimento de competências para o convívio social e também para o trabalho remunerado" (ibidem, p. 72).

Cabe ressaltar que as políticas voltadas para o trabalho prisional é uma das competências da Coordenação de Trabalho e Renda (COATR) do Departamento Penitenciário Nacional (Depen) e também envolve outras coordenações, responsáveis pela articulação com outros órgãos do Governo Federal. A COATR incumbe-se da efetivação dos direitos previstos no Fundo Penitenciário Nacional (Funpen), ${ }^{18}$ a fim de proporcionar a harmônica integração social dos presos (fim expressamente declarado), incluindo-os em políticas públicas voltadas à integração, ao mercado de trabalho e à profissionalização. ${ }^{19} \mathrm{O}$ foco principal do Depen (finalidade manifesta) é qualificar os presos para o mercado laboral, oferecendo cursos de capacitação profissional e a implementação de oficinas permanentes para capacitar o preso de acordo com as demandas do mercado de trabalho em liberdade. ${ }^{20}$

Segundo o Depen, até 2010, a criação de oficinas recebia recursos do governo federal após a análise de projetos elaborados dos Estados interessados e o modelo predominante era o convênio. Na prática, relatam gestores entrevistados, a "burocracia" dificultava a implantação das propostas, em parte pela ausência de padronização das demandas, com pedidos complexos e pouco objetivos, desafiando a necessidade de criar um novo modelo para alocação de recursos federais, o que começou a ser revisto em 2012 (MINISTÉRIO DA JUSTIÇA, 2013, p. 7).

Uma das imagens difundidas entre os gestores entrevistados era a de que o sistema penitenciário brasileiro buscava ser autossuficiente para gerir demandas, sem atentar que muitas de suas ações integravam políticas estruturadas de outros ministérios, cuja articulação interministerial poderia contemplar a população prisional, na medida em que o preso mantém todos os direitos constitucionais não afetos pela pena, entre eles o trabalho, a educação e a saúde. ${ }^{21}$

Assim, optou-se que as demandas do Depen relacionadas à saúde prisional fossem inseridas no âmbito das ações políticas do Ministério da Saúde; as educacionais no âmbito das ações do Ministério da Educação e aquelas afetas ao trabalho e à qualificação profissional fossem inseridas como parte das políticas públicas afetas ao Ministério do Trabalho e Emprego. Conforme enfatiza o Depen, a proposta "visa a expansão e aperfeiçoamento dos programas e projetos de assistência à saúde, à educação, à capacitação profissional intra e extramuros como forma de reintegração social dos presos e egressos do sistema prisional” (MINISTÉRIO DA JUSTIÇA, 2013, p. 8). 
Em relação ao trabalho do preso, as ações do Depen concentraram-se em dois programas específicos: o Programa de Capacitação Profissional e Implementação de Oficinas Permanentes (Procap), elaborado e coordenado pelo Depen, e o Programa Nacional de Acesso ao Ensino Técnico (Pronatec), elaborado e coordenado pelo MEC, no qual o Depen inseriu a população prisional por meio de acordos de cooperação entre os Ministérios envolvidos.

Com formatações distintas e finalidades diversas, o Procap é executado pelo próprio Depen, enquanto o Pronatec, criado em 2011 e cujo objetivo é ampliar a oferta de cursos de educação profissional e tecnológica à população brasileira, ${ }^{22}$ insere a população prisional, com a criação de um formato específico de qualificação nas unidades prisionais ou a inserção de presos que estão no regime semiaberto, nos cursos oferecidos para toda a sociedade por meio de instituições de ensino que oferecem cursos profissionalizantes para atender demandas do mercado de trabalho.

Ao inserir a população carcerária no Pronatec, política pública coordenada pelo Ministério da Educação, as aplicações dos recursos do Funpen focaram outras ações coordenadas pelo Depen. Cabe ressaltar que o acesso ao Pronatec possibilita, ao encarcerado, além da capacitação profissional, o benefício da remição pelo estudo previsto no art. 126 da LEP, resultando na redução de um dia de pena a cada 12 horas de estudo, com possibilidade de acréscimo de $1 / 3$ da remição se o preso concluir um ciclo completo de ensino durante o cumprimento da pena. ${ }^{23} \mathrm{~A}$ proposta com o Pronatec era capacitar 90 mil presos do sistema penitenciário até 2014, ${ }^{24}$ com previsão de alocar 180 milhões de reais para essa finalidade. ${ }^{25} \mathrm{Na}$ primeira etapa, os cursos seriam oferecidos fora das unidades prisionais para os presos dos regimes aberto, semiaberto e para os egressos do sistema prisional. Na segunda etapa, prevista para 2014, os cursos seriam oferecidos nas salas de aula das próprias unidades prisionais aos presos em regime fechado e provisórios. ${ }^{26}$

Já o Procap, programa idealizado pelo Depen, teve o foco inicial para os presos do regime fechado e fomentou a criação de oficinas de capacitação permanente nas unidades prisionais. Nesse sentido, buscando a padronização e a otimização dos recursos disponibilizados, o Depen definiu a verba de 300 mil reais para os Estados contemplados ${ }^{27}$ e privilegiou Estados há mais tempo sem receber recursos da União e aqueles que mostraram maior eficiência na gestão de recursos em projetos anteriores. No Procap, cada Estado define quais oficinas irá implementar entre aquelas impostas pelo Depen e otimiza a quantidade de oficinas de acordo com o recurso disponibilizado.

Assim, se há recursos disponibilizados para os projetos que visam ao trabalho prisional em regime fechado, a primeira conclusão possível é que o principal óbice à implantação do trabalho em regime fechado não decorre da total indiferença dos formuladores de políticas penitenciárias, mas envolve a decisão governamental e a iniciativa de cada Estado na efetivação de projetos. Coincidentemente, segundo o Depen, 
há maior desinteresse desse programa nos Estados com os piores indicadores no sistema prisional.

\section{RePrESENTAÇÕES SOCIAIS SOBRE A POLÍTICA PENITENCIÁRIA NO Distrito Federal}

O diagnóstico inicial apresentado interpela especialistas e atores que participam da gestão, da fiscalização e da execução da política penitenciária nacional. Ao conhecer as representações sociais dos atores envolvidos nas políticas penitenciárias no Distrito Federal, é possível lançar novas reflexões sobre as racionalidades punitivas, assim como identificar contradições discursivas compartilhadas pelos sujeitos da pesquisa. Essa estratégia metodológica parte da premissa de que, com base nas representações sociais, é possível adensar o conhecimento sobre práticas sociais de distintos atores e organizações relevantes em relação ao tema. Assim, sugerimos hipóteses para compreender alguns dos entraves e das dificuldades para a inserção do trabalho prisional no regime fechado.

Conforme informa o Depen, em 2014, havia um déficit maior que 231 mil vagas no sistema penitenciário brasileiro (MINISTÉRIO DA JUSTIÇA, 2014). As vagas existentes, além disso, não atendem aos objetivos explicitados na LEP. As imagens e representações sociais sugerem convergências e divergências entre os entrevistados. Se o trabalho prisional deve integrar o projeto reabilitador da LEP, qual a razão para a ausência de investimentos? Se é verdadeira a crença de que o trabalho prisional é peça-chave no modelo ideal, que razões explicam a sua inaplicabilidade, reafirmando-se a mensagem da pena como castigo e neutralização dos indivíduos perigosos? As representações sociais de juízes de direito, promotores de justiça, gestores e executores sugerem algumas posições comuns. Apontam que o sistema penitenciário participa no processo de degradação humana do condenado e frustram o ideal reintegrador do modelo clínico da LEP.

Nos relatos dos diferentes atores envolvidos, direta ou indiretamente, com a gestão, fiscalização ou execução da política penitenciária, a absoluta falta de planejamento e investimentos na área seriam fundamentais para compreender a ineficácia do modelo legal. O escasso valor político dos programas partidários que dedicam espaço nas agendas para a discussão da política penitenciária seria determinante para compreender a alocação dos recursos públicos e a deficiência crônica de condições materiais e humanas no setor.

Há, contudo, diferenças importantes nas narrativas dos sujeitos da pesquisa. Não se trata de um bloco homogêneo. As narrativas revelam-se marcadas pela necessidade de nomeação e classificação, naquilo que Moscovici denominou de ancoragem e objetivação. O primeiro conceito refere-se à redução de categorias e imagens comuns. Ao nomear as coisas e eventos, algo abstrato torna-se concreto e palpável, permite objetivá-lo (MOSCOVICI, 2003, p. 60-62). 
Conforme sistematização proposta nos itens seguintes, as narrativas estão ancoradas no mundo compartilhado pelos atores, o que revela distintas visões, crenças e valores.

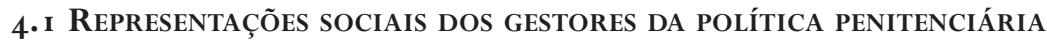

Os gestores do sistema penitenciário, peças-chave na idealização dos programas a serem implantados, relatam a importância do trabalho prisional no regime fechado. Nas entrevistas com os gestores, destacamos algumas categorias relevantes para analisar a ineficácia do trabalho prisional sob a ótica desses profissionais. As razões fundamentais podem ser classificadas em dois blocos distintos: de um lado, a responsabilidade dos políticos, que não dedicam a atenção devida ao tema, ausente da agenda dos partidos; de outro lado, a “cultura da prisão" seria refratária à construção de iniciativas bem-sucedidas neste campo da política penitenciária.

Um aspecto relevante é o reconhecimento da necessidade de mudanças na concepção da política penitenciária. Apontam-se a ineficiência do modelo existente, inclusive no funcionamento do Depen, e a escassez de recursos. Desperta a atenção do analista em políticas públicas a forma como os gestores associam cultura da prisão e obstáculos ao trabalho prisional. Na visão desses profissionais, a carência de servidores e de recursos materiais conforma práticas orientadas por "cultura voltada para a segurança”, chave para compreender as dificuldades para a implantação de eventuais políticas dirigidas ao setor. Nesse sentido:

É impossível hoje você pensar numa política isolada...todas essas áreas temáticas como saúde, trabalho, educação do sistema penitenciário... tudo isso deve ser pensado como partes de um todo... hoje, o sistema penitenciário deixou de achar que ele dá conta de tudo...até a década de 90, nos anos 2000, a ideia que se tinha era que o sistema penitenciário dava conta de tudo... e não dá .... o sistema penitenciário não consegue dar conta de tudo... Hoje tudo culmina para que as políticas do cárcere passem a integrar as políticas já existentes... O sistema penitenciário não é algo fora da sociedade... Muitos dizem: ah! O cara está preso, ele está à margem da sociedade...e ele [o preso] não está à margem da sociedade... ele está inserido na sociedade porque o sistema penitenciário é uma realidade da sociedade. Basta lembrar que não há pena perpétua e [pena] de morte...e ele voltará para a sociedade... (Gestor 1)

As narrativas dos gestores caracterizam-se pela utilização de razões técnicas. Em mais de um momento, há preocupação em buscar base teórica para os argumentos apresentados. As representações sociais dos gestores contemplam interpretações sobre o sentido da prisão. As racionalidades punitivas, muitas vezes traduzidas aos textos legislativos, também aparecem reproduzidas nas narrativas sobre as penas. $\mathrm{O}$ 
relato de um gestor entrevistado associa o trabalho prisional à humanização da pena, em sintonia com a concepção da nova defesa social, teoria inspiradora da LEP (ANCEL, 1979, p. 282). Na visão que aposta no potencial "humanizador" do cárcere, o trabalho prisional teria um papel fundamental, porém não receberia a devida atenção na pauta de prioridades políticas. Outro gestor aposta nas iniciativas de capacitar o preso durante o cumprimento da pena. O modelo existente, com foco na fase final da pena, teria escasso efeito na trajetória do condenado. Além disso, o relato indica que a cultura dominante dificultaria a implantação de políticas públicas:

Em temos de construção da política penitenciária... Embora haja um consenso sobre a necessidade de disponibilizar educação e o trabalho em presídios... de propiciar a possibilidade de cárceres menos desumanizados... O investimento nisso é muito baixo... o investimento é muito baixo nessa iniciativa... A perspectiva de trabalho no ambiente prisional é uma perspectiva de humanização... da possibilidade da pessoa ter acesso ao exercício de uma atividade... que faz bem a pessoa [do preso] enquanto ser humano... se nós retiramos também isso da pessoa [do preso] ... nós estamos cada vez mais retirando espaços de humanidade e de dignidade dessa pessoa... (Gestor 5)

Eu acho que é uma questão de cultura... Muito se fala hoje que o egresso sai sem qualificação nenhuma... sem documentos... sem ter noção do que vai fazer quando sair [do sistema penitenciário] ... Todos falam 'nós temos que qualificar o egresso'... Não... Nós temos que qualificar o preso... porque o preso vai virar o egresso... Você não qualifica e não auxilia o cara [o preso] nos últimos dois meses de pena... Então... antes dele sair [ganhar a liberdade] ... (Gestor 1)

O diagnóstico sobre a ineficácia da política voltada ao trabalho prisional também não se restringe ao saber técnico. Um dos relatos apoia-se em conhecimento prático e impressão sobre a necessidade de repensar as atividades de gestão e execução de políticas públicas. No Distrito Federal, o trabalho prisional historicamente teria recebido pouca atenção no regime fechado. Na sua avaliação, a ousadia do executor seria um diferencial importante para a implantação da política pública. O que supõe, por exemplo, um novo perfil para quem dirige as instituições carcerárias:

Eu vejo que os números de presos trabalhando pioraram... Nós não podemos ter nenhum preso trabalhando por experiência, por dedicação ou por voluntariedade... Todos os presos tem que receber salário... e eu vejo que... em tempos pretéritos... não vou muito longe... em 2006... 
Nós tínhamos aproximadamente 500 presos do regime fechado trabalhando dentro do sistema penitenciário... Eu volto na tecla da administração penitenciária... Então o Diretor penitenciário precisa ter um plus... além de Diretor precisa ser gestor... (Gestor 3)

A falta de interação entre os atores do sistema de justiça criminal também aparece na fala de um dos gestores como entrave à política penitenciária. A morosidade do Poder Judiciário no julgamento de presos provisórios agravaria o problema de falta de vagas nas instituições penitenciárias, e seria parte da "cultura do encarceramento" que orienta as práticas de magistrados, promotores de justiça, entre outros atores envolvidos na execução das penas. Nesse sentido:

A espera [de julgamento no Brasil] dos presos provisórios é uma vergonha... a questão dos presos provisórios em qualquer país do mundo e ainda mais em um país como o Brasil, de proporções continentais, é uma vergonha... São quase 300 mil vagas [com presos provisórios] e 300 mil vagas é vaga pra caramba... o Brasil não precisava dessa quantidade de vagas [se houvesse apoio a alternativas penais]... mas atualmente precisa... é um mal necessário, mas você pode ir, aos poucos, abrindo os olhos do Poder Judiciário...Tem Estados [brasileiros] que 78 por cento dos presos são provisórios... tem Estado que é 45 [por cento], outros é 55 [por cento]... isso é um absurdo... então, não é só o sistema penitenciário... todo o sistema de justiça criminal precisa abrir os olhos... Ah, se diz que o [Poder] Executivo não abre vagas... não tem onde colocar [o preso]... os agentes [penitenciários] não são capacitados... muitos entram [no serviço público] sem capacitação nenhuma... não tem recursos pra comprar comida [para os presos]... eu concordo... o [Poder] Executivo tem uma série de demandas que tem que resolver mesmo... só que o [Poder] Judiciário não é só para aplicar a pena não.. Tem que começar a entender o que a legislação diz de uma maneira mais abrangente...entender a realidade [social]... Tem casos de preso encarcerado por ameaça que estava preso provisoriamente há 7 meses... Se esse preso for condenado, [possivelmente] a pena aplicada será substituída [menor potencial] e ela não deveria estar um só dia presa... é um absurdo... (Gestor 1)

Ainda que os papéis institucionais sejam legalmente bem definidos, as narrativas dos gestores apontam a falta de sintonia entre as organizações e os atores diretamente relacionados à fiscalização da execução penal. O principal entrave não seria a legislação, mas a imposição de penas de prisão, nem sempre necessária, a morosidade processual e o que é descrito de forma sintética como "cultura punitiva”. Esses fatores atuariam 
diretamente na implantação das políticas penitenciárias e frustrariam o ideal reabilitador inscrito no ideário da LEP.

\subsection{REPRESENTAÇÕES SOCIAIS DOS PROMOTORES DE JUSTIÇA E DOS JUÍZES DE DIREITO}

As representações sociais dos promotores de justiça e magistrados recomendam agrupar em um único bloco de análise, embora sejam perceptíveis algumas diferenças, fruto de experiências profissionais e acadêmicas distintas. O ponto de convergência associa-se aos papéis desempenhados por profissionais que ocupam carreiras jurídicas. As falas são extremamente críticas em relação aos políticos e os argumentos são construídos a partir da autoridade abalizada de quem domina a linguagem jurídica. Os juristas, tanto teóricos quanto práticos, nas visões compartilhadas por promotores e juízes, teriam "pouco a fazer". Os políticos seriam os grandes "vilões" das promessas não cumpridas da LEP.

Entre os promotores entrevistados, predomina a visão de que faltariam projetos para o setor. As razões seriam variadas. No rol de prioridades, em perspectiva que não diverge dos demais sujeitos da pesquisa, o investimento teria pouca adesão em relação ao público. Além disso, os destinatários da política penitenciária estariam temporariamente alijados da participação política. Nesse sentido:

Eu [Estado] estou te mostrando que eu prendo, mas não queira, [é isso que, na minha opinião, o Estado pensa] ... Não queira que eu [Estado] invista nessa clientela do sistema prisional... Essa clientela não é minha prioridade [do Estado] ... Até por uma questão... Essa clientela não vota... O professor da escola vota... O pai que tem o filho na escola vota... E mesmo assim as políticas públicas no setor educacional são absurdas... São pífias também... Você não tem uma boa qualidade... No Brasil nós não temos essa visão... De que a coisa pública precisa funcionar... E no sistema prisional, até mesmo pelo princípio da menor elegibilidade... Até porque tem outras prioridades na segurança pública, etc. Você [o Estado] ... se acomoda mais... Você [o Estado] ... age menos... Então a eleição de prioridades [pelo Estado] está invertida... Ela [a visão que o Estado tem do sistema penitenciário] precisa de um projeto (Promotora de justiça 3)

Os relatos sobre a implantação de atividades laborais nas unidades prisionais de regime fechado do Distrito Federal sugerem interpretações distintas. Aqueles que participam diretamente na concepção e formatação dos programas (gestores) não parecem estar de acordo com os atores envolvidos na fiscalização e execução das políticas penitenciárias. As narrativas dos promotores de justiça explicitam visão de que teria havido retrocesso. No diagnóstico da realidade distrital, teria havido uma diminuição do número de presos inseridos nas atividades de trabalho prisional. A timidez em repensar o 
modelo atual seria agravada pelo regime de horários. Na prática, optou-se pelo encarceramento, útil como estratégia de contenção e neutralização dos perigosos. Nas representações sociais, a ausência de planejamento seria a explicação fundamental. Em sintonia com os relatos dos gestores, a predominância da "cultura da segurança" repercute na formatação do modelo prisional. Do modelo arquitetônico ao regime de horários, variam os motivos que afugentariam a iniciativa privada:

Vamos adotar que esse discurso de ressocialização seja algo pra levar a sério... Ressocializar significa então que você dará instrumentos à pessoa... Mesmo que seja minimamente... Há anos atrás... o número de postos de trabalho dentro dos presídios [regime fechado] era maior... e não cabe dizer que é porque a população aumentou... (Promotora de justiça 3)

A maior preocupação do servidor é não ser agredido pelo preso... não entrar na linha de ação de alguma agressão e manter aquele indivíduo encarcerado... [...]. A pessoa [o agente] vê primeiro no preso um agressor... Tem todo um procedimento... Faz todo um "mis en scène" para tirar um preso da cela... O sistema penitenciário do Distrito Federal tem um problema que é a vedação de visitas [aos presos] nos finais de semana... Para o desenvolvimento de atividade laborativa isso é um grande empecilho... (Promotora de justiça 2)

As representações sociais desses profissionais não se estruturam apenas segundo razões jurídicas e práxis de quem atua na área. Um dos relatos destaca-se por investir em reflexões teóricas sobre o tema, inclusive de fundo criminológico. Entre as diversas implicações que o tema interpela ou sugere, a narrativa aponta dissonância entre o trabalho prisional e a realidade do mercado de trabalho em liberdade. Ao buscar fundamentos teóricos para a exposição do tema, a participante diferencia-se das narrativas estritamente pragmáticas ou, de qualquer forma, associadas ao senso comum. A fala articula-se a partir de literatura crítica e reconhecida no campo penal. Na extensa descrição, menciona expressamente a crítica de Bauman (1999, p. 119) às mudanças sociais e econômicas impulsionadas pela globalização, especialmente no contexto das relações de trabalho. No mesmo relato, explicita a crítica de Deleuze e Guatarri (2004, p. 11 e ss.), ao associar a prisão a uma organização esquizofrênica, direcionada para a dissociação do eu:

Antes, você vendia força de trabalho e hoje? ... Você vende cérebro... você vende inteligência... você vende capacidade de pensar... Nós vivemos numa sociedade globalizada, volátil... e da informação... O preso do regime fechado... ele não tem acesso a esse tipo de coisa... Quer ver? ... Vamos colocar estudo para os presos do regime fechado... Vamos colocar cursos profissionalizantes... pedreiro... carpinteiro... seja lá o que for... São cursos 
que... não vão deixar [os presos] preparados para o mercado de trabalho... esses cursos deixarão os presos com alguma coisa... uma ferramenta mínima para tentar não morrer de fome... Hoje o que se vende é a capacidade de pensamento... A forma do sistema prisional no Brasil... é uma organização “esquizofrênica”... porque ela afirma uma coisa e ela nega... Ela afirma que vai ressocializar... mas ela nega isso na hora que termina com o 'eu' da pessoa. (Promotora de justiça 3)

Os relatos dos promotores de justiça são igualmente críticos em relação à lógica do sistema. No jogo entre os discursos legislativos, explicitam-se as contradições entre as promessas políticas traduzidas em textos legais e as práticas penitenciárias. As funções expressas (ideologias "re") cedem espaço às práticas estritamente punitivas. Reafirmamse as funções latentes do sistema:

A situação é muito ruim... Começa que o preso sai de lá [do sistema penitenciário] muitas vezes sem o dinheiro da passagem [de transporte]... começa daí... Se coloca no lugar dele [do preso]... Se você estava preso e ganha a liberdade... você precisa no mínimo de um dinheiro pro almoço... pro jantar... Pelo menos para um dia [de sustento] e nem isso ele [o preso] tem... Aí as pessoas [sociedade] falam assim: "nossa mas que índole terrível desse preso”... Não é isso...também [deve ser olhada] a falta de condições [do preso]... Esse é um viés cruel do sistema penitenciário... Nós [Estado e sociedade] cobramos [do preso] mas sem dar a mínima condição para que aquela cobrança seja atendida [pelo preso] ... São os “3 R” [reintegração, recuperação e reinserção] que nunca acontecem... E isso não é somente no Brasil. (Promotora de justiça 1)

Nos relatos dos juízes de direito entrevistados, um dos temas recorrentes é o discreto papel das políticas penitenciárias na agenda política. Para uma mudança estrutural, o caminho não é fácil. Muitas vezes, opta-se por ignorar que o preso será devolvido à sociedade após cumprir a pena. O tema também não gera a indignação da sociedade organizada. Aparentemente, na síntese das falas, "para a sociedade, quanto mais tempo encarcerado melhor”. Esta visão também repercute na agenda dos partidos políticos e ações das agências encarregadas da implantação de políticas públicas. Apenas com a reformulação radical da visão pautada pelos meios de comunicação de massa, reproduzida no senso comum e nos discursos políticos seria possível pensar em mudanças em médio prazo:

O problema prisional não é prioridade... em nenhuma política pública... para nenhum governante. Qual é a pergunta mais comum que a gente 
ouve? ... É melhor construir um hospital ou um presídio? ... é melhor colocar o professor numa sala de aula ou dentro do presídio? ... é melhor colocar o médico no hospital ou dentro do presídio? ... Então, o descaso histórico com o sistema prisional gerou necessariamente vários desafios (Juiz de direito 4).

Basta perguntar a quem agrada uma obra no sistema penitenciário. Quem fica feliz com uma obra no sistema penitenciário? A população não é... Porque a população fica feliz se você construir uma nova rodoviária... Se você construir um novo hospital... algo que ela possa ver... A obra no sistema penitenciário é uma obra que não aparece, uma obra que não gera dividendos eleitorais, ela não gera uma satisfação pra população... A sociedade quer aquela ilusão de que fechada a porta da cadeia ela não precisa mais se preocupar... Isso é bom pro cidadão... Ele dorme tranquilo quando ele pensa "está preso" ... Mas ele não pensa que daqui há dois anos e meio, um ano e meio ele [o criminoso] estará junto com ele [o cidadão] de novo (Juiz de direito 1).

A maior parcela da população carcerária brasileira, segundo dados do Depen, ${ }^{28}$ cumpre pena em regime fechado. Além disso, é nesse regime, em tese, que o preso cumprirá a maior parte da pena. No entanto, o cenário demonstra escassas oportunidades para o trabalho prisional. 29 Os juízes de direito, assim como os gestores, enfatizam a importância do trabalho prisional durante o regime fechado como o momento crucial para o cumprimento da pena e, por meio de ações políticas efetivas, prepararia o terreno para a progressão de regime. Embora a LEP não priorize o trabalho em um ou outro regime prisional, observa-se que, aqueles presos que se encontram no regime semiaberto ocupam maior atenção na agenda política. 30 Nesse sentido:

O sentenciado que está no regime fechado... Ainda está naquela lógica da segurança pública... na visão da sociedade... É o preso que está esquecido... Quando o preso passa para o regime semiaberto... onde necessariamente eu [Estado] sou obrigado a reconhecer alguns direitos que implicam em liberdade... Me parece que surge uma natural preocupação [com o trabalho prisional]... porque eu [Estado] não posso manter o preso do semiaberto em um regime análogo ao fechado... Então pra não cometer uma ilegalidade... Existe uma preocupação maior de conceder a ele [o preso do regime semiaberto] um trabalho externo... Creio que a preocupação é essa... E penso que está errado... O trabalho deve começar aqui... No primeiro dia do cumprimento da pena... Principalmente no regime fechado... Porque ele produz um efeito no dia a dia da cadeia... (Juiz de direito 4) 
As representações sociais dos juízes de direito também buscam apoio no saber teórico, especialmente o conhecimento jurídico-penal. As narrativas dos juízes de direito contemplam e descrevem as diferentes racionalidades punitivas, transformadas e reinventadas, especialmente a partir do século XVIII. A complexidade da programação do poder punitivo associa-se à concorrência de diferentes discursos que justificam e legitimam as penas. Dessa forma, o ideal ressocializador, reafirmado pela ideologia da defesa social, matriz teórica que inspirou a LEP, convive com o comando repressivo-preventivo do art. 59 do Código Penal brasileiro. Os magistrados são críticos em relação às políticas públicas. Um dos relatos remete às proposições de Von Liszt no século XIX (1995, p. 82-83). Na visão do penalista alemão, o ideal ressocializador poderia ser efetivo para a maioria dos reclusos, muito embora, influenciado pela criminologia positivista, sustentasse que a prisão perpétua deveria ser reservada para os incorrigíveis:

Só abrir vaga não resolve nada... Porque a execução penal teria que punir, prevenir e reeducar a pessoa... Nós só estamos punindo... Eu acho que dentro desse universo de 100 por cento [de presos], você tem um percentual de 92 por cento que tem conserto e querem ser consertados... Pode ter certeza... Eles [os presos] querem ser classificados para o trabalho... Querem fugir da cela, da extorsão onde estão, numa cela que seria pra 8 presos e está com 20 presos... Ele [o preso] quer uma possibilidade melhor. (Juiz de direito 3)

Os relatos dos juízes de direito, observadores privilegiados das promessas descumpridas da LEP, sugerem diferentes variáveis para a compreensão do que é descrito como "cultura da segurança". Nessa visão, prevalecem as práticas que limitam o alcance do comando legal, o que remete de forma explícita ao diagnóstico compartilhado pelos gestores:

É muito difícil entrar no regime fechado porque existe um preconceito muito grande... e também por que... Isso não é uma crítica, porque eu sei das dificuldades que se tem... Mas há uma certa resistência... Até de diretores de presídio... Porque o manejo do preso no regime fechado ou no regime semiaberto sem benefício... é um manejo difícil... Você às vezes precisa adaptar o expediente a um horário diferenciado para que o preso possa trabalhar... ou seja... Você mexe com uma área de conforto que já existe há muito tempo... É muito mais fácil você manter o preso encarcerado 24 horas do que tirar ele para trabalhar... ou estudar... Então tudo isso age contra [o trabalho no regime fechado] também... (Juiz de direito 1). 
As motivações organizacionais não são irrelevantes na avaliação dos magistrados. O trabalho prisional também repercute nas rotinas dos executores (agentes penitenciários, especialmente). A definição das tarefas também se relaciona à economia dos esforços. O horizonte de melhoria na qualidade de vida do recluso com a inserção no trabalho prisional perde terreno se identificado risco à segurança da unidade prisional. Reafirma-se, assim, o castigo. O discurso da reintegração social seria reservado para aqueles que se fazem merecedores e, em momento distinto, alcançado com a progressão do regime. Nessa lógica, o regime fechado é ressignificado como momento ou etapa da "expiação". Reservado para a reflexão sobre os atos praticados pelo preso:

Me parece que a lei trabalha com a lógica de que no regime fechado o preso é "plenamente incapaz", [o preso] progride para [o regime] semiaberto que é a "puberdade" até chegar no [regime] aberto... onde a lei fala que o preso se guiará pelo seu senso de autodisciplina e auto responsabilidade... Me parece que o trabalho no regime fechado... é onde eu teria a punição... Por isso eu chamo de penitenciária... É hora dele fazer penitência, de refletir...” o pai [o Estado] colocou ele [o preso] no quarto (na cela) e ele só sai de lá quando o pai [o Estado] autorizar”... depois de [cumprir] 1/6 [da pena] ele já refletiu... Então eu [Estado] começo a dar as oportunidades para ele [o preso]... Mas o sujeito [o preso] estava no regime fechado ontem... hoje ele está no semiaberto... o que mudou nesse sujeito [preso] de ontem pra hoje?... Somente a forma jurídica... antes ele era totalmente temido e agora eu [Estado] já posso confiar um pouquinho nele... Eu [Estado] estou dizendo que posso confiar não pelo que ele [o preso] é... mas pela classificação que eu [Estado] dei à ele... (Juiz de direito 2)

O modelo normativo brasileiro determina que, em regra, o condenado retorne ao convívio social. Certamente, esse "retorno" interpela juristas e cientistas sociais sobre as múltiplas racionalidades punitivas. Os altos índices de reincidência sugerem os efeitos “criminógenos" do cárcere. ${ }^{31}$ Embora ainda faltem estudos empíricos que associem a inserção em atividades laborais à diminuição da criminalidade ou aos índices de reincidência, certamente o trabalho prisional, repensado sob o enfoque humanista, poderia, ao menos, minorar o processo de degradação (desconstrução do “eu”) do indivíduo que normalmente integra uma instituição total com as características de uma penitenciária. Na reformulação do conceito de reintegração social, ao despir o conceito de sua pretensão invasora e transformadora das subjetividades, o trabalho prisional pode ser redimensionado como parte de uma estratégia dirigida à diminuição de danos (BARATTA, 1991, p. 253). Essa breve descrição surge nos relatos dos sujeitos da pesquisa quando se menciona o retorno ao convívio social daquele que foi submetido ao regime prisional brasileiro. $\mathrm{Na}$ visão compartilhada pelos magistrados, existem muitas razões que 
poderiam explicar o escasso espaço do tema na agenda política. As propostas ou programas partidários relevantes para o sistema penitenciário normalmente são etiquetados pelos juízes de direito como "de baixo capital político". A cultura do controle, associada ao populismo punitivo, alimentaria a paranoia difundida e reproduzida pelo discurso criminológico midiático (ZAFFARONI, 2012, p. 261). Um dos juízes de direito sugere que a própria sociedade não veria com bons olhos os investimentos nessa área. O que acabaria legitimando a inação política em relação ao sistema penitenciário:

Aquele que sai do sistema hoje... sai pior... Eu acho que a sociedade hoje... Ela não se encontra em sintonia com a nossa Lei de Execuções Penais... A impressão que eu tenho... Pelo que eu vejo na mídia, nos jornais, nas revistas e na opinião pública... É que a sociedade não quer só a punição... Ela quer muito mais que a punição... Ela quer a prisão perpétua... Ela quer a pena de morte... Ela quer diminuir a maioridade penal... Mesmo nós [sistema penitenciário] devolvendo uma pessoa muito pior para a sociedade... por falta de estrutura... por falta de condições... pela própria filosofia do sistema... Ainda assim nós [sistema penitenciário] não estamos atendendo a expectativa da sociedade [...]. (Juiz de direito 4)

Outro magistrado enfatiza o papel do cárcere como reprodutor das desigualdades sociais e processos de exclusão social. O relato reafirma a crítica à incoerência do discurso reintegrador, que supõe a implantação do modelo que contempla a prevenção especial positiva com as práticas de exclusão e isolamento social:

Como é que você quer que um latrocida... que passou 10 anos no sistema [penitenciário]... Na hora dele ganhar a liberdade... eu tenho que dar a ele a passagem de ônibus... Como é que você quer que ele não volte [para o sistema penitenciário] ... O trabalho e o estudo são fundamentais para que ele [o preso] saia com uma perspectiva... O sujeito é retirado do esgoto... encontra-se enterrado no crack... eu determino que ele seja incluído em um tratamento rigoroso e intensivo... Esse sujeito passa um ano no sistema [penitenciário] e quando ele progride de pena novamente... eu pergunto para ele: Qual tratamento você recebeu? ... Nenhum Doutor... Os outros internos me davam açúcar por causa da abstinência [do vício]. (Juiz de direito 3).

$\mathrm{Na}$ visão dos magistrados - o que também é sugerido nas falas dos promotores de justiça -, a realidade da execução penal brasileira é pródiga em paradoxos. Por um lado, aposta-se na possibilidade de melhoria do modelo. As deficiências são gigantescas e inúmeros são os abusos. Em um horizonte de degradação humana, não raramente as racionalidades punitivas cedem espaço às urgências que as crises e tragédias interpelam. 
As contradições entre as finalidades das penas aparecem nos relatos dos sujeitos da pesquisa: "Nós prendemos, colocamos o preso no sistema e no ano de 2014 estamos nos perguntando: E agora? O que vamos fazer com o preso?" (Juiz de direito 4).

O dispositivo da TRS permite aprofundar algumas questões sobre as representações sociais dos participantes da pesquisa, atores diretamente envolvidos na execução das penas no Distrito Federal. Entre os profissionais da carreira jurídica predomina a frustração diante do limite de atuação na área. Magistrados, promotores e advogados "fazem o que podem", atuam conforme os programas jurídicos disponibilizados. Contudo, a garantia de direitos pressupõe, especificamente em relação ao tema da pesquisa, de investimentos estatais. Predomina a crença de que o investimento no sistema carcerário não é prioridade política. Na ausência de mobilização para a mudança do status quo, os atores não sugerem caminhos em um horizonte próximo. Ao contrário, predomina o pessimismo e o "nada funciona".

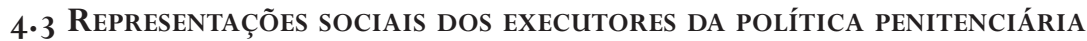

As representações sociais dos executores podem ser agrupadas segundo categorias relevantes para a nossa análise. O saber prático de quem atua no interior das prisões é um dos fios condutores de suas narrativas sobre a prisão e sobre as possibilidades do trabalho prisional, inclusive em regime fechado. Diferentemente das falas dos gestores, movidas pela interdisciplinaridade ou as narrativas de juízes e promotores, fundadas em conhecimentos dogmáticos e criminológicos, as representações dos executores estão marcadas pelas práxis de quem "conheceria de perto" e "vivenciaria as rotinas" das prisões.

De início, um dos pontos destacados mostra a convergência com os relatos dos demais sujeitos da pesquisa. A percepção generalizada de que a implantação integral dos dispositivos da LEP sempre perdeu e perderá espaço no jogo da política. Os servidores designados para acompanhar as rotinas de uma penitenciária são igualmente céticos em relação à viabilidade de ações efetivas para uma mudança radical da política penitenciaria e redirecionamento para a reintegração social:

Eu não tenho ideia sobre os pensamentos que [os Governantes] tem do [sistema penitenciário] ... Mas eu penso que a [construção] de uma escola é mais visível que [a construção] de uma cadeia... da mesma forma que [a construção] de um viaduto é mais visível que [a construção] de uma rede de esgotos... Eu comparo [a construção] da escola à construção de um viaduto e [a construção] de uma cadeia [à construção] de uma rede de esgoto... Parece que ninguém vê quando [o Governo] constrói uma cadeia... [Nessa mesma opinião] Por que construir uma rede de esgotos se eu [Governo] tenho dinheiro para construir um viaduto... e ele [o viaduto] vai embelezar a minha cidade... (Executor 3) 
As diferentes racionalidades punitivas, transformadas e reinventadas ao longo do século XX, não são irrelevantes. A produção legislativa pode ser identificada como campo fértil para análise das dinâmicas, muitas vezes contraditórias, em que os discursos que justificam e legitimam a pena são traduzidos e transpostos aos textos legais. Se a LEP contemplou e traduziu o ideal preventivo (especial positivo), reproduzido nas ideologias "re" - modelo clínico (art. $1^{\circ}$ ) -, os discursos dos atores que integram diferentes organizações responsáveis por diferentes etapas da implantação, execução e fiscalização da política penitenciária, sugerem a concorrência de múltiplas racionalidades punitivas. A semântica do trabalho prisional associa-se às distintas concepções sobre a sua inserção durante o cumprimento da pena privativa de liberdade. Para os executores, que vivenciam o cotidiano das penitenciárias, premidos pelas regras e rotinas de uma instituição total (GOFFMAN, 1999, p. 16), o trabalho prisional não aparece associado necessariamente ao ideal clínico que ele supostamente operaria nas subjetividades. No jogo de interesses, os papéis assumidos pelos diferentes atores que convivem e interagem também podem se relacionar à implantação do trabalho prisional no regime fechado. A disciplina e o controle surgem nos relatos como fatores relevantes, e novos significados podem ser atribuídos ao trabalho no regime fechado. As descrições sintetizam as mensagens legitimadoras da política pública: "acalmar o cárcere" e "fomentar o espírito colaborativo" (FOUCAULT, 2007, p. 107). Alguns dos relatos são exemplificativos:

No transcorrer desses anos... eu pude perceber que o trabalho... ele influencia positivamente no relacionamento interno e também externo, no caso do egresso. Essa influência positiva vai desde [o tratamento] do interno [do preso] com o servidor, com o profissional da segurança, do interno [do preso] com os profissionais da saúde e da educação e do interno [do preso] com o próprio interno [preso] ... Em certo aspecto há o interesse direto pela remição... Essa influência é positiva... Porque o interno [o preso] tem muito a perder no caso de uma possível desclassificação... (Executor 2)

As falas dos executores reproduzem também o senso comum, em expressões como "o trabalho enobrece o homem". No entanto, a percepção de quem convive (os executores) com o preso sugere razões estratégicas ou dramatúrgicas (GOFFMAN, 1988 , p. 146) que orientariam os comportamentos no cárcere. O trabalho prisional, ainda que desarticulado do ideal reabilitador, seria valorado pelos presos, conforme avalia um dos executores:

O trabalho em si é algo que enobrece... E o preso se sente enobrecido... agradecido... O agente penitenciário muda o comportamento dele em relação àquele preso que trabalha... é um outro relacionamento... Você 
precisa colocar o interno pra trabalhar... Por uma questão de ressocialização... de ressocialização e as vezes de socialização porque ele nunca foi socializado... nunca existiu ali um cidadão... Mas a grande maioria, eu percebo que somente quer trabalhar pela remição e para diminuir [o tempo] de encarceramento. Eu noto que aquele interno [preso] que faz a limpeza da ala... aquilo ali para ele é estar livre do cárcere... [...] Nós colocamos na mão dele [do preso] um rodo e um balde de água e ele acha isso muito bom... Porque vai poder ficar fora da sua cela... Ele pensa assim: Eu estou fora da minha cela... Eu estou num mundo de liberdade... (Executor 3).

A chamada "cultura da segurança” no regime fechado, recorrente nas falas dos gestores e profissionais das carreiras jurídicas (promotores de justiça e juízes de direito), não é ignorada pelos executores. Alguns dos relatos aparecem como assunção de culpa ou responsabilidade. Segundo um dos relatos, o "não" surge como resposta natural e automática a qualquer proposta ou iniciativa que contemple o trabalho no regime fechado, se relacionada a qualquer indício de fragilidade para a segurança interna. Fatores operacionais também são relevantes. A carência de vagas e falta de servidores seriam obstáculos importantes. Nesse sentido:

Não podemos pensar somente na segurança... Pensando na segurança há uma tendência natural de dizer não... Dizendo não, você não se expõe e deixa o preso 22 horas dentro da cela e 2 horas no banho de sol... Mas o preso recolhido muito tempo dentro da cela aumenta o nível de stress... As válvulas de escape que são o trabalho, o estudo, o banho de sol, a cantina ou a visita ${ }^{32} \ldots$ Se nós começamos a cortar isso, porque é mais fácil dizer não e deixar o preso dentro da cela... Nós recebemos de volta uma carga muito pior... Quando você começa a falar muito sobre ressocialização... você começa a ouvir piadinhas dos servidores... O Diretor é bonzinho... o chefe é bonzinho... Mas esse é o foco da execução penal... Nós precisamos tentar ressocializar o preso... de 3100 internos $^{33}$ se nós conseguirmos salvar $1 \ldots$ eu acho que a missão já foi cumprida... (Executor 1)

A penitenciária precisa ter duas coisas essenciais... [a primeira] é a vaga para o preso... O preso tem que ter direito à sua vaga... à sua cama... [a segunda] é gente [servidores] pra cuidar dele [para vigiar o preso] ... Então, não adianta falarmos da possibilidade de aumento de oficinas se nós não temos sequer uma cama para o preso deitar... Se o Estado não está se importando em criar vagas para os presos... quem dirá criar vagas de trabalho dentro da penitenciária [...]. (Executor 3) 
Alguns dos executores são críticos em relação às opções de política penitenciária para o trabalho prisional e às escolhas na gestão dos recursos público. O regime fechado é preterido nas tomadas de decisões relacionadas à alocação de recursos para o trabalho prisional. As motivações, aparentemente, são variadas. Entre as possíveis razões pragmáticas, a necessidade de agir preventivamente diante de possíveis rebeliões ou motins:

Está invertido... O Estado investe pesado no preso que está no semiaberto... Que em tese é aquele preso que... Ou praticou um crime menos grave e foi condenado no regime semiaberto ou, se praticou um crime mais grave, já cumpriu um tanto de pena no regime fechado e já mostrou bom comportamento... Olhando assim, de forma crua... Quem menos precisa é quem mais tem... (Executor 1)

Nos relatos dos executores surgem também críticas à dificuldade de operacionalizar o trabalho em regime fechado sem meios suficientes para viabilizar o deslocamento dos internos. Sem um número suficiente de profissionais, haveria risco efetivo para a segurança interna. Os riscos em uma penitenciária são constantemente observados e desafiam as rotinas estabelecidas. A escassez de servidores e de meios leva (ou ao menos justifica a inação) ao cerceamento das atividades educacionais e laborais.

Em extenso relato que contextualiza as condições humanas do processo de globalização econômica, Bauman (1999, p. 119) cunha a expressão "lixo social” para se referir ao output humano produzido pelo maquinário punitivo. Entre os entrevistados, a expressão surge no relato de um dos sujeitos da pesquisa. $\mathrm{Na}$ descrição detalhada de um dos executores, a penitenciária lida com o lixo social:

Eu costumo falar que eu trabalho com o "lixo social" ... Sem uma visão discriminatória. Mas aquilo que a sociedade rejeitou, eu recebo aqui... O aluno que não deu certo lá fora... O trabalhador que não deu certo lá fora...Eu tenho que recebê-lo e lapidar... Ele volta pior para a sociedade... Fala-se no senso comum que a cadeia... a penitenciária é um PHD, um doutorado... pelas más influências... Tudo aquilo de bom que talvez ele tenha aprendido na sociedade... ele acaba esquecendo aqui [no sistema penitenciário] ... Esse "lixo social” ... ele acaba devolvido à sociedade... menos lapidado se comparado quando ele entrou [no sistema penitenciário] ... (Executor 2)

Nos relatos dos entrevistados, a prática penitenciária aparece dissociada do modelo idealizado pela LEP (art. $1^{\circ}$ da Lei n. 7.210). No caleidoscópio de imagens e descrições das rotinas carcerárias, os sujeitos da pesquisa sugerem as contradições 
do que é descrito como sociedade punitiva. As mensagens que ecoam dos meios de comunicação direcionam o foco e a agenda para o endurecimento das penas e repressão. ${ }^{34} \mathrm{O}$ relato de um dos entrevistados explicita (e sintetiza) as ambiguidades que a prisão ainda suscita entre os sujeitos inseridos na teia de relações de uma instituição total:

Eu tenho comigo... que daqui a 200 anos... a sociedade irá rir... vai sorrir mesmo... Irá criticar esse modelo de cárcere que nós vivemos hoje... Como nós rimos do calabouço de antigamente... onde se fritava o braço no azeite quente... onde a mesma vasilha em que se comia o alimento, se colocava as fezes... [...] Imagine uma pessoa ficar dentro de um "quadradinho" ... nós estamos falando de seres humanos... ficam dentro de um quadradinho 22 horas... e em um pátio... recebendo um banho de sol por 2 horas... [...] sem fazer nada... (Executor 3)

As narrativas podem, uma vez mais, ser aprofundadas a partir da TRS. A ausência de estrutura material e humana para dar efetividade ao comando da LEP leva à insatisfação generalizada em relação ao modelo instalado, pois não se identifica um horizonte de mudança do panorama descrito nos relatos dos participantes da pesquisa. Ao contrário, a ausência de condições mínimas no ambiente carcerário desloca o foco do objeto da pesquisa. As críticas dirigem-se à precariedade das prisões, descritas como ambiente sem as mínimas condições para atender ao ideal ressocializador, que acaba transformado, no contexto prisional, em motivo de "piada" na fala dos executores. Nesse contexto, a ausência de estrutura para o trabalho prisional em regime fechado desaparece ou é obscurecido pelo extenso rol de mazelas das prisões, relacionadas nas longas descrições dos sujeitos da pesquisa.

O pessimismo em relação à implantação do trabalho prisional leva a atribuições recíprocas de responsabilidades pelo completo esvaziamento da política pública. As referências à "cultura da segurança" do cárcere surgem como pano de fundo dos relatos dos participantes da pesquisa e configuram dispositivo que atua para dissipar eventual responsabilização pessoal. Atribuir a responsabilidade pela implantação da política pública à suposta "cultura da área" dilui eventual culpa pelo funcionamento inadequado ou pelo distanciamento das políticas públicas idealizadas. Em outras palavras: o sistema não funciona, entre outras razões, por culpa da "cultura da segurança”.

\section{Conclusões}

O foco deste artigo foi, após o mapeamento inicial, indagar e discutir iniciativas e ações políticas relacionadas ao trabalho prisional no regime fechado no Distrito Federal, a partir das representações sociais de alguns dos atores diretamente envolvidos na gestão, fiscalização e execução penal. 
Embora o ideal reintegrador configure o modelo legal de execução penal contemplado na LEP, o objetivo declarado mostra-se de difícil implantação. As práticas dos atores envolvidos na divisão do trabalho penitenciário sugerem a concorrência de outras racionalidades punitivas, especialmente a retribuição e a prevenção geral negativa. As dificuldades em se atender às exigências técnicas do Governo Federal para a liberação de recursos e a falta de capacitação técnica das burocracias estaduais agravam a operacionalização das políticas idealizadas pelos gestores. O distanciamento entre o modelo idealizado pela LEP e a realidade do sistema penitenciário brasileiro evidenciam que a previsão legal não alterou a precariedade das políticas penitenciárias voltadas à capacitação profissional no regime fechado.

Em que pesem os projetos dirigidos à implantação do trabalho prisional em regime fechado, no Distrito Federal a análise documental exploratória detectou que um dos entraves fundamentais ocorre na etapa de execução dos projetos, o que sugere reflexões. O funcionamento das oficinas laborais nas unidades do regime fechado está diretamente ligado à atuação da Funap. Se não houver projetos, os espaços permanecerão inutilizados, deficiência apontada nas falas dos sujeitos da pesquisa. Outro fator merece destaque: se houver projetos e a estrutura funcional for deficitária, característica do sistema penitenciário brasileiro, onde a escassez de "tudo" predomina, a tendência é a manutenção da segurança em detrimento do trabalho prisional.

Nota-se ainda que, nos últimos 6 anos houve a diminuição de atividades laborais remuneradas dirigidas aos presos em regime fechado no Distrito Federal. A situação é confrontada pelos sujeitos da pesquisa, os quais identificam supostos "efeitos positivos" em relação ao comportamento prisional quando ocorre a inserção do interno em atividades de trabalho ou estudo. Porém relata-se que as atividades laborais e educacionais se subordinam aos interesses do sistema e não à capacitação profissional do condenado.

As narrativas dos gestores orientam-se pelo mundo da técnica. O familiar associa-se à ocupação desempenhada por esses profissionais. As explicações dos gestores quanto à idealização e implantação de políticas públicas apresentam-se em discursos orientados pelo saber técnico. Em outras palavras, a expertise do "profissional das políticas públicas”.

O saber técnico funda-se na interdisciplinaridade de equipes de trabalho que reúnem profissionais de distintas áreas de conhecimento, voltados à concreção das políticas penitenciárias. De forma marcadamente distinta das representações sociais dos executores, os gestores analisam cuidadosamente a peculiaridade do regime fechado, o que faria deste regime o mais adequado para a formação profissional em áreas determinadas.

$\mathrm{Na}$ fala desses profissionais, a responsabilização pela ineficácia das políticas públicas não lhes seria atribuível. As representações sociais apontam responsáveis, que ocupam polos opostos na cadeia de políticas públicas. De um lado, os relatos indicam o 
mundo da política como grande “vilão", pois, na visão dos executores, iniciativas voltadas à população carcerária receberiam pouco ou nenhum espaço nas agendas partidárias. De outro lado, as representações desses profissionais associam problemas dificilmente solucionáveis na execução penal. Na fala dos gestores, "a cultura da prisão" seria um dos entraves determinantes à implantação da política de trabalho prisional em regime fechado. Nessa perspectiva, desenha-se horizonte pessimista quanto a possíveis mudanças, pois esbarrariam em questões cruciais, não apenas relacionadas a ações políticas dirigidas à reforma e adequação do ambiente prisional, mas também à resistência dos executores.

As narrativas de juízes de direito e promotores de justiça, como profissionais do mundo do direito, ancoram-se no referencial jurídico que fundamenta e confere consistência aos argumentos apresentados (MOSCOVICI, 2003, p. 60-63). A necessidade de contemplar o regime fechado articula-se diretamente ao modelo idealizado pela LEP. O discurso dos "direitos" articula-se com questões práticas, próprias das legislações com déficit de implantação, e surgem as comparações com outros diplomas legais que dependem de ações efetivas do Estado, de investimentos públicos. Assim como os gestores, juízes de direito e promotores de justiça atribuem a responsabilidade pela ineficácia da política pública ao inexistente interesse político despertado pelo trabalho prisional. As representações sociais estão marcadas por expressões ancoradas no papel assumido pelas instituições do sistema de justiça, que atuam segundo o horizonte programado pela legislação penal e processual penal. A atividade jurídica deve estar balizada pelos direitos fundamentais e regras estabelecidas pela LEP. Porém, sem investimentos efetivos, seria muito restrito o impacto da atuação de juízes de direito, promotores de justiça e outros profissionais do direito. A razão para o "nada funciona" atribui-se aos políticos, indiferentes à realidade prisional, e que tornariam nulas as promessas "inscritas na LEP".

O pessimismo explicitado nas falas de juízes de direito e promotores de justiça teria razões profundas, tanto sociais quanto econômicas e políticas. A população carcerária seria vista pela sociedade, e não apenas pela classe política, como "escória”, indigna da utilização de recursos públicos. Estes deveriam ser realocados para áreas de interesse social, rol no qual não se contemplaria o investimento em melhoria de condições das prisões ou adequação das instalações para atender aos objetivos da LEP. As falas remetem à visão compartilhada pelos profissionais da área jurídica: a responsabilidade pelo descumprimento do comando legal não lhes é atribuível. Decorre de escolhas políticas, pois depende de investimentos.

As narrativas dos executores associam as políticas penitenciárias à realidade das prisões. Os executores reivindicam o conhecimento prático, desconhecido por "profissionais de gabinete" ou "burocratas" distantes das rotinas do cárcere. O familiar, nas falas dos executores, remete à política penitenciária descrita como "possível”.

Ao reivindicar mais condições de trabalho e estrutura material e humana, as narrativas sinalizam diferentes funções das penas. Os discursos dos executores sugerem 
que o regime fechado é o momento de "expiação da culpa", retratado por esses profissionais como necessário. Nos relatos, a primeira fase seria uma forma de purgar a culpa pelo "mal cometido". A construção discursiva atenua eventuais falhas estruturais detectadas na pesquisa de campo.

O saber prático dos executores também contempla parte das racionalidades punitivas que conformam os saberes penais e criminológicos. O regime fechado, em descrição explicitada na fala de alguns dos executores, é o momento do exercício da retribuição penal. A pena, inclusive, deve ser, narram os executores, um castigo exemplar. Nesse ponto, a argumentação deixa transparecer o senso comum sobre a razão das penas, mas na voz dos executores busca a autoridade do saber prático de quem "vivenciaria a realidade; que a conhece na prática e não apenas nos livros".

A TRS constitui-se em ferramenta teórica útil para abordar a implantação de políticas públicas. Neste artigo, a análise do trabalho prisional em regime fechado no Distrito Federal fundamentou-se nas representações sociais de alguns dos atores diretamente envolvidos em distintas fases da idealização e execução da política penitenciária. O enfoque permitiu adensar a compreensão dos significados do trabalho prisional, os entraves para a eficácia das medidas estabelecidas e os discursos que justificam a ineficácia das normas contempladas em diferentes diplomas legais, especialmente na LEP.

NOTAS

1 Sobre a diferenciação funcional dos sistemas jurídico e político, ver Luhmann (2005, p. 359 e ss e 473 e ss; 2007 , p. 471 e ss). Conferir análise da diferenciação interna do subsistema jurídico penal (MACHADO, 2014, p. 49 e ss).

2 Sobre a teoria da evolução e as categorias variação, seleção e estabilização: (LUHMANN, 2007, p. 393-399).

3 Especialmente em relação às disputas e influências de comunidades epistemológicas na produção do direito penal, ver Enguéléguélé (1998, p. 563-581).

4 O vocábulo "trabalho" origina-se do latim tripalium. Literalmente, instrumento de tortura, aquilo que fatiga ou provoca dor. Na etimologia da palavra trabalho (tripalium), designa instrumento romano de tortura, espécie de tripé formado por três estacas cravadas no chão, onde eram supliciados os escravos "tri" (três) e "palus" (pau) literalmente, "três paus". De onde deriva o verbo tripaliare (ou trepaliare), que significava, inicialmente, torturar alguém no tripalium. Entre os séculos XII e XV, a palavra trabalho remetia à experiência dolorosa. Apenas no século XVI o vocábulo é associado a obra ou labor. À obra (poiesis) do homem artista e livre, ao labor (poneros) do homem pressionado por outro ou pela natureza, acrescentou-se então o trabalho ao ritmo da máquina. Assim, o vocábulo 
"trabalhador" associou-se ao agricultor e o operário. No fim do século XIX, os três últimos termos mal se distinguiam entre si (ILLICH, 1974, p. 52).

5 Zaffaroni refere-se ao conjunto de teorias orientadas pela prevenção especial positiva como ideologias "re". Sobre o tema, consultar Roxin (2001, p. 89); Munoz Conde (2001, p. 72); Mir Puig (2002, p. 56); e Zaffaroni (2011, p. 116).

6 Segundo o Depen, dos 607.731 presos no Brasil, pouco mais de 58 mil presos trabalham, o que representa $16 \%$ da população prisional. Os demais (84\%) não estão inseridos em nenhuma atividade laboral. Entre os que trabalham, $72 \%$ estão inseridos em atividades intramuros e $24 \%$ trabalham externamente. Nesse sentido, consultar Ministério da Justiça - INFOPEN 2014.

7 As entrevistas em profundidade foram realizadas por Marcos Aurélio Sloniak, segundo projeto amplamente discutido com Bruno Amaral Machado, orientador da dissertação aprovada em 31 de março de 2014, no Programa de Mestrado em Direito e Políticas Públicas do Uniceub. Os autores são responsáveis pela divulgação das entrevistas neste artigo.

8 A Funap/DF foi criada pela Lei n. 7.533, de 2 de setembro de 1986, e seu funcionamento está previsto no Decreto n. 10.144, de 19 de fevereiro de 1987.

9 Essa possibilidade está prevista no art. 34 da LEP e representa significativa formatação dos sistemas penitenciários estaduais que gerenciam essa atividade por meio de fundações.

10 Sobre os órgãos de execução penal, consultar os arts. 61 ao 81 da LEP.

11 Ministério da Justiça. PRONASCI: Um novo paradigma para a Segurança Pública. Cartilha Institucional, p. 3-6.

12 Ministério da Justiça. PRONASCI: Ações Estruturais. Disponível em: <http://portal.mj.gov.br/main.asp? View= $\{3$ FD 1029 C - C 70B-4394-A 81 E-A 52 F 2E42E 259$\} \&$ BrowserType $=$ IE \& LangID = pt-br\&params $=$ itemID\%3D\%7BA798EE9A-7471-4D92-A96D-0FA8B55925FE\%7D\%3B\&UIPartUID=\%7B2868BA3C-1C72-4347BE11-A26F70F4CB26\%7D>. Acesso em: 27 ago. 2013.

13 Lei n. 11.530, de 24 de outubro de 2007. Institui o Programa Nacional de Segurança Pública com Cidadania e dá outras providências. Art. $3^{\circ}$, VIII.

14 Ministério da Justiça. DEPEN. Plano Diretor do Sistema Penitenciário do Distrito Federal 2007. Disponível em: <http: / portal.mj.gov.br/main.asp?View =\%7B71FD341F-0531-4BAB-A567-586745CB18\%7D\&Team=\&params $=$ itemID $=\% 7 B 2 A C 5 E C 2 A-C 783-4 C 72-9 B 14-5 B E 75 D 88371 \% 7 D ; \& U I P a r t U I D=\% 7 B 2868 B A 3 C-1 C 72-4347-B E 11$ A26F70F4CB26\%7D>. Acesso em: 20 nov 2013.

15 O Distrito Federal inaugurou a padaria na Penitenciária do Distrito Federal em 25 de março de 2014. Com instalações modernas e investimentos de cerca de 2 milhões de reais, a estrutura prevê a fabricação diária de 80 mil pães e deve abrir 40 novas vagas de trabalho remuneradas para presos daquela Unidade Prisional. "PAPUDA ganha panificadora, meta é produzir 80 mil pães por dia”. Disponível em: <http://www.df.gov.br/noticias/item/13138papuda-ganha-panificadora-meta-\%C3\%A9-produzir-80-mil-p\%C3\%A3es-por-dia.html>. Acesso em: 2 abr. 2014.

16 Plano Diretor do Sistema Penitenciário. 2010. p. 21. Disponível em: <http://portal.mj.gov.br/ main.asp? View $=\% 7 B 71 \mathrm{FD} 341 \mathrm{~F}-0531-4 \mathrm{BAB}-\mathrm{A} 567-72586745 \mathrm{CB} 18 \% 7 \mathrm{D} \& \mathrm{Team}=\&$ params $=$ itemID = \% 7B2AC5EC2A-C7834C72-9B14-5BE75D88371\%7D; \&UIPartUID=\%7B2868BA3C-1C72-4347-BE11-A26F70F4CB26\%7D>. Acesso em: 20 nov. 2013. Essa mesma informação consta no documento da FUNAP de outubro de 2013, intitulado "Release".

17 Ministério da Justiça. Programa para sistema prisional quer zerar déficit de vagas femininas. Disponível em: <http:/ / portal.mj.gov.br/data/Pages / MJ7CBDB5BEITEMID1 ADB977D573D4D978CD4C0102521503APTB RIE.htm>. Acesso em: 30 ago.2013.

18 O Fundo Penitenciário Nacional foi criado pela Lei Complementar n.79, de 7 de janeiro de 1994, com a finalidade de proporcionar recursos e meios para financiar e apoiar as atividades de modernização e aprimoramento do Sistema Penitenciário Brasileiro. O Funpen foi regulamentado pelo Decreto n. 1.093, de 23 de março de 1994 e 
entre suas finalidades dispõe no Art. $3^{\circ}$, os recursos do Funpen serão aplicados em: implantação de medidas pedagógicas relacionadas ao trabalho profissionalizante do preso e elaboração e execução de projetos voltados à reinserção social de presos.

19 Ministério da Justiça. Apoio ao trabalho e renda e qualificação profissional para presos, internados e egressos do Sistema Penitenciário Nacional. Disponível em: <http://portal.mj.gov.br/cnpcp/main.asp? ViewID=\%7BDA8C1EA2

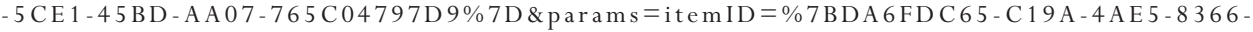
35ECE41D0085\%7D; \&UIPartUID=\%7B2868BA3C-1C72-4347-BE11-A26F70F4CB26\%7D>. Acesso em: 20 ago. 2013.

20 Ministério da Justiça. Ações de trabalho, renda e qualificação profissional. Disponível em: <http://portal.mj. gov.br/cnpcp/main.asp? Vi ew = \% 7 B D A 8 C 1 E A 2 - 5 C E 1 - 45 B D - A A $07-5765$ C 04797 D $9 \%$ 7D\&Team $=$ \&params $=$ itemID $=\% 7 B C C A 31 B 27-5 D 4 F-4 D 32-82 F C-2 E 25 C F 666096 \% 7 D ; \&$ UIPartUID=\%7B2868BA3C1C72-4347-BE11-A26F70F4CB26\%7D>. Acesso em: 2 set. 2013.

21 Segundo o art. 203 da Constituição Federal, a assistência social será prestada a quem dela necessitar, independentemente de contribuição à seguridade social, e tem por objetivos, entre outros: "III - a promoção da integração ao mercado de trabalho”.

22 Ministério da Educação. O que é o Pronatec? Disponível em: <http://pronatec.mec.gov.br/institucional/ o-que-e-o-pronatec >. Acesso em: 10 set. 2013.

23 Lei n. 7.210, de 11 de julho de 1984. Institui a Lei de Execução Penal. Art. 126, § 5².

24 Pronatec destinará 90 mil vagas a presos e pessoas que já cumpriram pena. Disponível em: <http://memoria.ebc.com.br/agenciabrasil/noticia/2013-02-07/pronatec-destinara-90-mil-vagas-presos-epessoas-que-ja-cumpriram-pena>. Acesso em: 10 fev. 2014.

25 Segundo os gestores do Depen, o orçamento para a capacitação profissional com verbas do Funpen era de R\$ 6 milhões de reais. Com a possibilidade de inserir os presos no Pronatec a perspectiva de investimento passa para R\$ 180 milhões de reais.

26 Ministério da Justiça. Governo Federal abre 90 mil vagas para qualificar presos. Disponível em: < http: //portal.mj. gov.br/main.asp?ViewID=\%7BFB3ADAA8-2180-4AC8-BF99-44D4CC507EA\% 7D\&params=itemID=\%7BAB3FE8DA5F60-41D4-BF9F-9FEA5746F320\%7D; \&UIPartUID=\%7B2218FAF9-5230-431C-A9E3-E780D3E67DFE\%7D>. Acesso em: 10 set. 2013.

27 Dados do Procap. Disponível em: <http://www.justica.gov.br/seus-direitos/politica-penal/politicas-2/ trabalho-e-renda-no-sistema-prisional/acoes-de-trabalho-nas-prisoes>. Acesso em 1 abr. 2015.

28 Segundo o Departamento Penitenciário Nacional (Depen), o Brasil possuía em junho de 2014, mais de 607 mil presos. Destes, 250.094 cumpriam pena no regime fechado, enquanto 89.639 presos cumpriam pena no regime semiaberto 250.213 eram presos provisórios (MINISTÉRIO DA JUSTIÇA, 2014).

29 A LEP e o Código Penal preveem que o trabalho do preso será remunerado (art. 29 da LEP e art. 39 do Código Penal). De acordo com os dados da Funap-DF (release 2013, out. 2013, p. 9) o Distrito Federal possuía, em outubro de 2013, 155 vagas de trabalho remunerado para presos do regime fechado. Segundo o Depen, em junho de 2014 havia 6198 presos cumprindo pena no regime fechado no Distrito Federal o que representa a inserção, nessa atividade, de apenas 2,5\% dos presos que estavam cumprindo pena no referido regime. Nesse cálculo não foram computados os presos que exercem atividades sem remuneração e os presos envolvidos em atividades educacionais.

30 De acordo com os dados da Funap-DF (release 2013, out. 2013, p. 9) o Distrito Federal possuía, em outubro de 2013, 1977 vagas de trabalho remunerado para presos do regime semiaberto, das quais 1.294 estavam ocupadas. Em junho de 2014, o Depen informa que 3322presos cumpriam pena no regime semiaberto no Distrito Federal. Assim, as vagas da Funap indicam a inserção de 59,51\% dos presos em trabalho remunerado no regime semiaberto. Cabe ressaltar que esse percentual pode ser maior, vez que, empresários particulares também podem oferecer atividade remunerada aos presos do regime semiaberto, cujo procedimento passa, necessariamente, pelo 
crivo da Vara de Execuções Penais, após a manifestação do Ministério Público sobre a proposta apresentada pelo empresário interessado.

31 Os efeitos do encarceramento (prisonização) foram definidos for Donald Clemmer, autor do Livro A Comunidade Prisional, lançado em 1940 no qual retrata a rotina de funcionamento de uma penitenciária de segurança máxima em Illinois. Mais tarde esse tema foi retomado por Erving Goffman. Sobre o tema, ver: ANITUA, (2008, p. 511); GOFFMAN (1999, p. 24).

32 Zaffaroni (2012, p. 449) retrata o quanto esses valores simbólicos são importantes no cotidiano penitenciário e por vezes responsáveis pela eclosão de trivialidades, no que define "o cárcere fabricando cadáveres".

33 O executor refere-se ao quantitativo de presos cumprindo pena na Unidade à qual pertence. Segundo dados da Penitenciária do Distrito Federal (PDF), a unidade foi projetada para abrigar 1584 presos. Em junho de 2015 contava com 3.426 presos. Disponível em: http://www.cnj.jus.br/inspecao_penal/gera_relatorio.php?tipo_escolha= comarca\&opcao_escolhida=14\&tipoVisao=presos. Acesso em: 15 jun. 2015

34 Salo de Carvalho (2010, p. 151) destaca que, desde a década de 1990, algumas leis brasileiras endureceram o cumprimento da pena. Entre essas legislações, a Lei (n. 8.072/90) Lei de Crimes Hediondos, a mudança de critérios para obtenção de progressão de regime e a criação de novos tipos penais. Esse conjunto de fatores contribuiu para o aumento da população criminal.

\section{REFERÊNCIAS BIBLIOGRÁFICAS}

ANCEL, Marc. A nova defesa social: um movimento de política criminal humanista. Trad. Osvaldo Melo. Rio de Janeiro: Forense, 1979.

ANITUA, Gabriel Ignácio. História dos pensamentos criminológicos. Trad. Sérgio Lamarão. Rio de Janeiro: Revan, 2007. BARATTA, Alessandro. Resocialización o control social: Por um concepto crítico de "reintegración social" del condenado In: ARAÚJO JUNIOR, João Marcelo de. Sistema penal para o terceiro milênio: Atos do colóquio Marc Ancel. 2. ed. Rio de Janeiro: Revan, 1991.

BATISTA, Nilo. Punidos e mal pagos: violência, justiça, segurança pública e direitos humanos no Brasil de hoje. Rio de Janeiro: Revan, 1990.

BAUMAN, Zygmunt. Globalização: as consequências humanas. Rio de Janeiro: Jorge Zahar, 1999. . Vidas desperdiçadas. Rio de Janeiro: Jorge Zahar, 2005.

BECCARIA, Cesare. Dos delitos e das penas. São Paulo: RT, 1999.

BENTHAM, Jeremy. O panóptico. Belo Horizonte: Autêntica, 2008.

Teoria das penas legais e tratado dos sofismas políticos. São Paulo: Edijur, 2002.

. Uma introdução aos princípios da moral e da legislação. São Paulo: Abril Editora, 1979.

BERGER, Peter L.; LUCKMANN, Thomas. La construcción social de la realidad. Trad. Silvia Zuleta. Buenos Aires: Amorrortu, 1999.

BRUNER, Jerome. Actos de significado: para uma psicologia cultural. Lisboa: Edições 70, 1990.

CÂMARA LEGISLATIVA DO DISTRITO FEDERAL. Projeto de Lei n. 1569/2013. Institui o Projeto Remição

pela Leitura no âmbito dos Estabelecimentos Penais do Distrito Federal.

CARRARA, Francesco. Programa do curso de direito criminal. São Paulo: LZN, 2002.

CARVAlHO, José Murilo de. Os bestializados: o Rio de Janeiro e a República que não foi. São Paulo:

Companhia das Letras, 1987.

CARVALHO, Salo de. Crítica a execução penal. 2. ed. Rio de Janeiro: Lumen Juris, 2007.

. Teoria agnóstica da pena: entre os supérfluos fins e a limitação do poder punitivo. Crítica à

execução penal. Rio de Janeiro: Lumen Juris, 2007.

. Substitutivos penais na era do grande encarceramento. In: GAUER, Ruth Maria Chittó (Org.).

Criminologia e sistemas jurídicos penais contemporâneos II. Porto Alegre: PUCRS, 2010. 
CIONELLO, Alexandre et al. Segurança pública e cidadania: uma análise Orçamentária do Pronasci. Instituto de Estudos Socioeconômicos: Brasília, 2008.

CONSElho NACIONAL DE POlítiCA CRIMINAL E PENITENCIÁRIA. Plano Nacional de Política Criminal e Penitenciária. Brasília: CNPCP, 2011.

. Diretrizes básicas para arquitetura prisional. Brasília: CNPCP, 2011. Regras mínimas para tratamento dos presos no Brasil. Disponível em:

<http://portal.mj.gov.br/main.asp>. Acesso em: 15 ago. 2013.

DELEUZE, Gilles. Foucault. Trad. Cláudia Sant'Anna Martins. São Paulo: Brasiliense, 1988.

DEPEN. Plano Diretor de Melhorias para o Sistema Prisional. Brasília: 2013.

Sistema Integrado de Informações Penitenciárias. Brasília: 2013.

DISTRITO FEDERAL. Plano Diretor do Sistema Penitenciário do Distrito Federal - 2007. Disponível em: $<$ http://portal.mj.gov.br/main.asp?View =\%7B71FD341F-0531-4BAB-A567-72586745CB18\%7D\&Team= \& params $=$ itemID $=\% 7 B 2 A C 5 E C 2 A-C 783-4 C 72-9 B 14-65 B E 75 D 88>$. Acesso em: 20. nov. 2013.

Plano Diretor do Sistema Penitenciário do Distrito Federal - 2010. Disponível em:

$<$ http://portal.mj.gov.br/main.asp?View=\%7B71FD341F-0531-4BAB-A567-72586745CB18\%7D\&Team= \& params $=$ itemID =\%7B2AC5EC2A-C783-4C72-9B14-5BE75D88371\%7D; \&UIPartUID=\%7B2868BA3C $>$. Acesso em: 20. nov. 2013.

ENGUÉLÉGUÉLÉ, Stéphane. Les communautés épistémiques pénales et la production législative en matière criminelle. Droit et Societé, Paris, n. 40, 1998, p. 563-581.

FERRI, Enrico. Princípios de direito criminal: o criminoso e o crime. Trad. Paolo Capitanio. 2. ed. Campinas: Bookseller, 1999.

Sociologia criminal. Trad. Soneli Maria Melloni Farina. São Paulo: Minelli, 2006.

FOUCAULT, Michel. Vigiar e punir: a história da violência nas prisões. 34. ed. Rio de Janeiro: Vozes, 2007. FEUERBACH, Johan Paul Anselm von. Tratado de derecho penal comum vigente en Alemania. Trad.Eugênio Raul Zaffaroni e I. Hagemeier. Buenos Aires: Mannurabi, 1989

FUNDAÇÃO DE AMPARO AO TRABALHADOR PRESO DO DISTRITO FEDERAL. Release. 2013.

GAROFAlO, Raffaele. Criminologia. Trad. Danielle Maria Gonzaga. Campinas: Péritas, 1997.

GOFFMAN, Erving. Estigma: nota sobre a manipulação da identidade deteriorada. 5. ed. Rio de Janeiro: Guanabara, 1988 .

. Manicômios, prisões e conventos. São Paulo: Perspectiva, 1999

GUATARRI, Félix; DELEUZE, Gilles. O anti-édipo: capitalismo e esquizofrenia. Trad. Joana Moraes Varela e Manuel Maria Carrilho. Lisboa: Assírio\&Alvim, 2004.

HEGEL, Georg Wilhelm Friedrich. Fundamentos de la filosofia del derecho. Barcelona: Libertarias, 1994.

ILLICH, Ivan. Convivencialidad. Trad. GROSSMANN, Matea P de, Barcelona: Barral Editores, 1974.

JOVCHELOVITCH, Sandra. Psicologia social, saber, comunidade e cultura. Psicologia \& Sociedade, Porto Alegre, n. 2, v. 16, p. 20-31, maio-ago. 2004.

KANT, Immanuel. A metafísica dos costumes. São Paulo: Edipro, 2003. Doutrina do direito. São Paulo: Icone, 2003.

LINS E SILVA, Evandro. De Beccaria a Filippo Gramatica. In: ARAÚJO, João Marcello de Araújo Junior (Org.). Sistema penal para o terceiro milênio. 2. ed. Rio de Janeiro: Revan, 1991.

LOMBROSO, Cesare. O homem delinquente. Trad. Maristela Bleggi Tomasini e Oscar Antonio Corbo Garcia. 2. ed. Porto Alegre: Ricardo Lenz, 2001.

LUHMANN, Niklas. El derecho de la sociedad. Trad. Javier Torres Nafarrate. Cidade do México: Herder, 2005 . La sociedad de la sociedad. Trad. Javier Torres Nafarrate. Cidade do México: Herder, 2007.

MACHADO, Bruno Amaral. Discursos criminológicos sobre o crime e o direito penal: comunicação e diferenciação funcional. Revista de Estudos Criminais, v. 45, abr.-jun. 2012. A diferenciação interna do subsistema jurídico penal: história, organizações e trajetórias.

Revista de Estudos Criminais, n. 52, jan.-mar. 2014. . Justiça criminal: diferenciação funcional, organizações e decisões. São Paulo: Marcial Pons, 2014.

MINISTÉRIO DA EDUCAÇÃO. O que é o Pronatec? Disponível em:

<http://pronatec.mec.gov.br/institucional/o-que-e-o-pronatec>. Acesso em: 10 set. 2013.

MINISTÉRIO DA JUSTIÇA. Ações de trabalho, renda e qualificação profissional. Disponível em:

$<\mathrm{http}$ / / portal.mj.gov.br/cnpcp/main.asp?View =\%7BDA8C1EA2-5CE1-45BD-AA07-5765C04797D9\& Team= \& params $=$ itemID $=\% 7 \mathrm{BCCA} 31 \mathrm{~B} 27-5 \mathrm{D} 4 \mathrm{~F}-4 \mathrm{D} 32-82 \mathrm{FC}-2 \mathrm{E} 25 \mathrm{CF} 666096 \% 7 \mathrm{D}$; \& UIPartUID = \% 7B2868BA3C1C72-4347-BE11-A26F70F4CB26\%7D>. Acesso em: 2 set. 2013.

. Apoio ao trabalho e renda e qualificação profissional para presos, internados e egressos do Sistema

Penitenciário Nacional. Disponível em: <http://portal.mj.gov.br/cnpcp/main.asp?ViewID=\%7BDA8C1EA2- 
5CE1-45BD-AA07-765C04797D9\%7D\&params=itemID=\%7BDA6FDC65-C19A-4AE5-836635ECE41D0085\% 7D;\&UIPartUID=\%7B2868BA3C-1C72-4347-BE11-A26F70F4CB26\%7D. > . Acesso em: 20 ago. 2013.

. Cartilha sobre o Programa Nacional de Apoio ao Sistema Penitenciário. Brasília: 2013.

. Governo Federal abre 90 mil vagas para qualificar presos. Disponível em: <http://portal.mj.gov.br $/$ main.asp?ViewID=\%7BFB3ADAA8-2180-4AC8-BF99-544D4CC507EA \%7D\&params=itemID=\% 7BAB3FE8DA-5F60-41D4-BF9F-9FEA5746F320\%7D;\&UIPartU>. Acesso em: 10 set. 2013. . Plano Diretor do Sistema Penitenciário: Diagnóstico, ações e resultados. Disponível em: <http://portal.mj.gov.br/main.asp?ViewID=\%7B71FD341F-0531-4BAB-A567-72586745CB18\% 7D\&params=itemID=\%7BF329E71B-B4C8-40E2-BF58-F206>. Acesso em: 20 out. 2013. . Programa para sistema prisional quer zerar déficit de vagas femininas. Disponível em:

<http://portal.mj.gov.br/data/Pages/MJ7CBDB5BEITEMID1ADB977D573D4D978CD4C0102521503APT BRIE.htm>. Acesso em: 30 ago.2013. . Pronasci Ações estruturais. Disponível em: <http://portal.mj.gov.br/main.asp?View= $\{3 F D 1029 C-C 70 B-4394-A 81 E-A 52 F 2 E 42 E 259\} \&$ BrowserType $=$ IE\&LangID $=$ pt-br\&params $=$ itemID $\%$ 3D\%7BA798EE9A-7471-4D92-A96D-0FA8B55925FE\%7D\%3B\&UIPartUID=\%7B>. Acesso em: 27 ago. 2013. . Pronasci: um novo paradigma para a segurança pública. Cartilha Institucional. . Sistema Penitenciário Federal. Disponível em: <http://portal.mj.gov.br/main.asp? ViewID=\%7B887A0EF2-F514-4852-8FA9-D728D1CFC6A1\%7D\&params=itemID=\%7B5AC72BD6-09F649AE-BDB0-A5A1D5A28B9\%7D; \&UIPartUID=\%7B2868BA3C-1C72-4347-BE11-A26F70F4CB26\%7D>. Acesso em: 5 set. 2013.

MIR PUIG, Santiago. Introducción a las bases del derecho penal. 2. ed. Buenos Aires: Julio Cesar Faira, 2002. MOSCOVICI, Serge. Prefácio. In: JOVCHELOVITCH, S; GUARESCHI, P. Textos em representações sociais. Petrópolis: Vozes, 1994.

Representações sociais: investigações em psicologia social. Petrópolis: Vozes, 2003.

MUNOZ CONDE, Francisco. Introducción al derecho penal. Buenos Aires: Julio Cezar Faira, 2001.

PORTO, Maria Stela Grossi. Polícia e violência: representações sociais das elites policiais do Distrito Federal. São Paulo em Perspectiva, v. 18, n. 1, 2004.

. Crenças, valores e representações sociais da violência. Sociologias, Porto Alegre, ano 8, n. 16, 2006. . Sociologia da violência: do conceito às representações sociais. Brasília, Editora Verbena, 2010.

ROMAGNOSI, Giandomenico. Génesis del Derecho Penal. Bogotá: Têmis, 1956.

ROXIN, Claus. Derecho penal parte general: fundamentos la estructura de la teoría del delito. Trad. Diego Manuel Luzón Penã. 2. ed. Barcelona: Civitas, 2001.

SCHÜTZ, Alfred. La construcción significativa del mundo social: introducción a la sociología comprensiva. Trad. Eduardo J. Prieto. Barcelona: Paidós, 1993.

TRIBUNAL DE JUSTIÇA DO DISTRITO FEDERAL E TERRITÓRIOS. Nota a Imprensa. Disponível em: <http://www.tjdft.jus.br/institucional>. Acesso em: 10 set. 2013.

VON LISZT, Fran. La idea del fin en derecho penal. Buenos Aires: Granada, 1995.

ZAFFARONI, Eugenio Raúl. A palavra dos mortos. São Paulo: Saraiva, 2012. , et alli. Direito penal brasileiro. Rio de Janeiro: Revan, 2011.

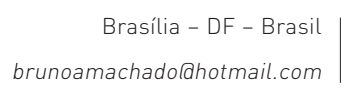

Bruno Amaral Machado

\author{
Pós-DOUTORADO EM SOCIOLOGIA \\ PELA UNIVERSIDADE DE BRASÍLIA. \\ DOUTOR EM SOCIOLOGIA JuRÍDICO-PENAL \\ PELA UNIVERSIDADE DE BARCELONA. \\ Professor dos Programas de Mestrado \\ e Doutorado em Direito do Uniceub.
}

Pesquisador Associado do Departamento de Sociologia da Universidade de Brasília. Professor do Programa de Doutorado em Ciências Penals da Universidade de San Carlos da Guatemala.

PROMOTOR DE JUSTIÇA EM BRASília. 
222 : DISCIPLINA OU RESSOCIALIZAÇÃO? RACIONALIDADES PUNITIVAS, TRABALHO PRISIONAL

\section{Marcos Aurélio Sloniak}

Brasília - DF - Brasil

matungolaterra.com.br
Mestre em Direito PELo Uniceub.

Especialista em Segurança Pública pela PUC do Rio Grande do Sul, Gestão de Pessoas pela Universidade

Federal Rural do Rio de Janeiro e Planejamento e Gestão de EAd pela Universidade Federal Fluminense.

Policial Civil no Distrito Federal. 